\title{
LEVEL II SCOUR ANALYSIS FOR BRIDGE 7 (SALITH00080007) on TOWN HIGHWAY 8, crossing the MIDDLEBURY RIVER, SALISBURY, VERMONT
}

U.S. Geological Survey Open-File Report 98-257

Prepared in cooperation with

VERMONT AGENCY OF TRANSPORTATION

and

U.S. Department of the Interior

U.S. Geological Survey

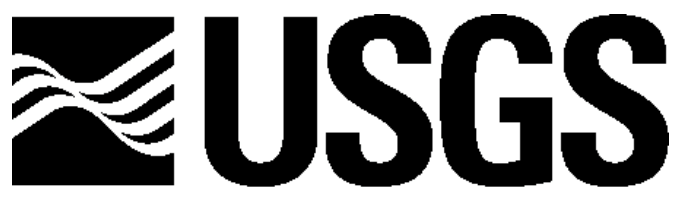




\section{LEVEL II SCOUR ANALYSIS FOR BRIDGE 7 (SALITH00080007) on TOWN HIGHWAY 8, crossing the MIDDLEBURY RIVER, SALISBURY, VERMONT \\ By ERICK M. BOEHMLER AND LAURA MEDALIE}

U.S. Geological Survey Open-File Report 98-257

Prepared in cooperation with

VERMONT AGENCY OF TRANSPORTATION and

FEDERAL HIGHWAY ADMINISTRATION 


\title{
U.S. DEPARTMENT OF THE INTERIOR BRUCE BABBITT, Secretary
}

\author{
U.S. GEOLOGICAL SURVEY
}

Thomas J. Casadevall, Acting Director

For additional information write to:

District Chief

U.S. Geological Survey 361 Commerce Way

Pembroke, NH 03275-3718
Copies of this report may be purchased from:

U.S. Geological Survey

Branch of Information Services

Open-File Reports Unit

Box 25286

Denver, CO 80225-0286 


\section{CONTENTS}

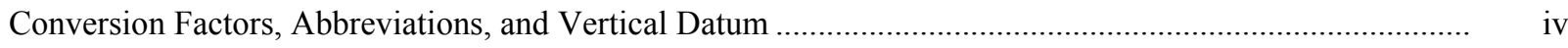

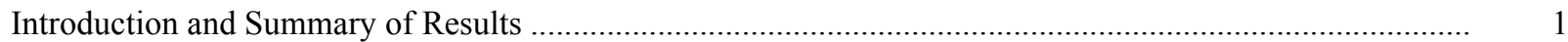

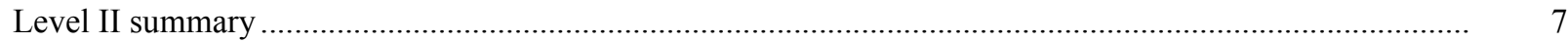

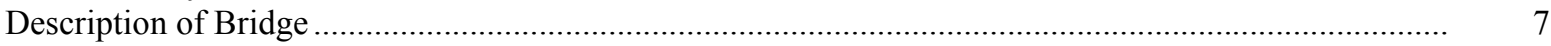

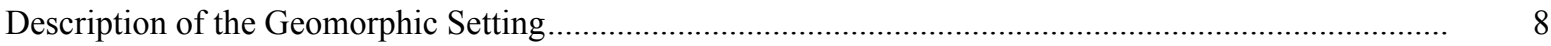

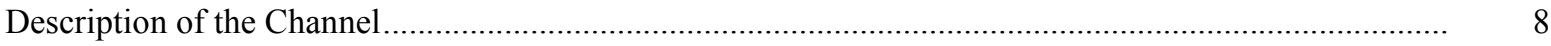

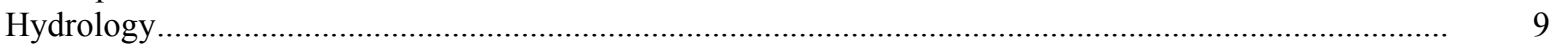

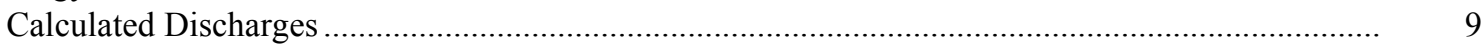

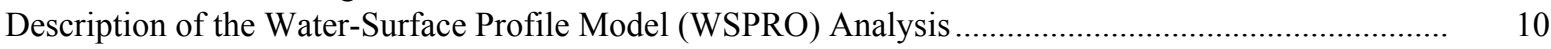

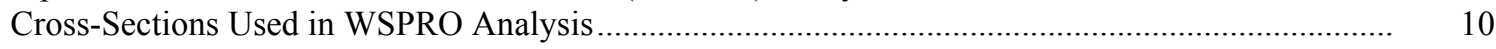

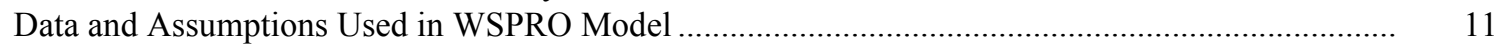

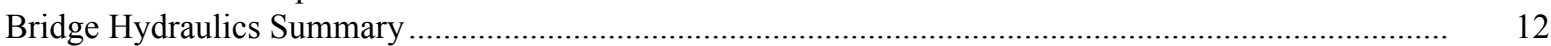

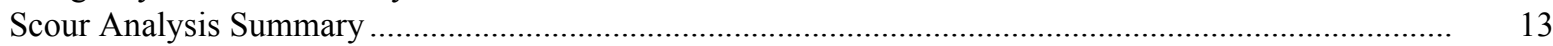

Special Conditions or Assumptions Made in Scour Analysis ..................................................... 13

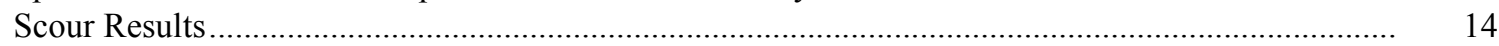

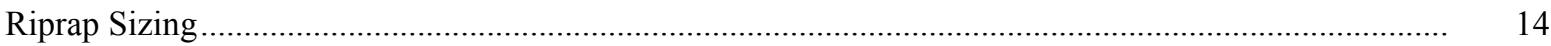

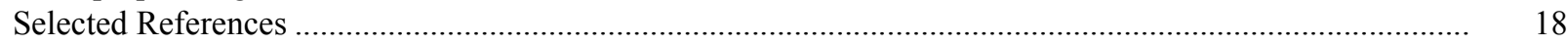

Appendices:

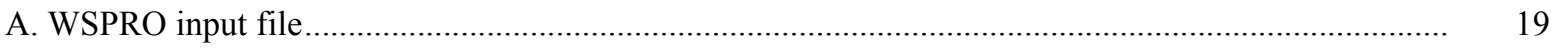

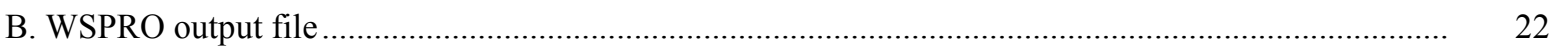

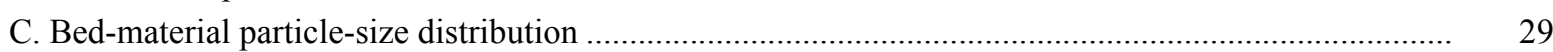

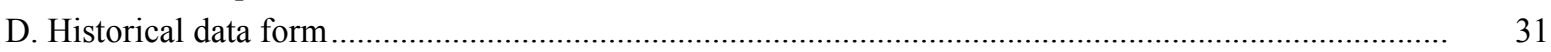

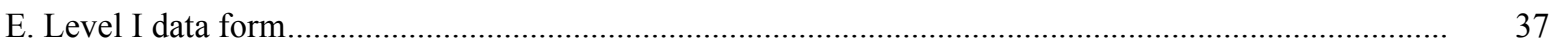

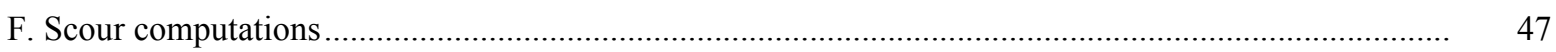

\section{FIGURES}

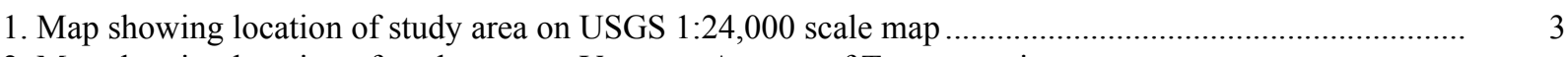

2. Map showing location of study area on Vermont Agency of Transportation town

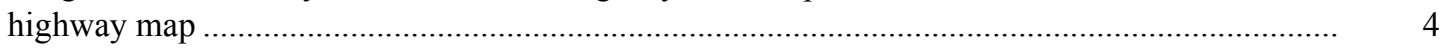

3. Structure SALITH00080007 viewed from upstream (June 17, 1996) ...............................................

4. Downstream channel viewed from structure SALITH00080007 (June 17, 1996).................................. 5

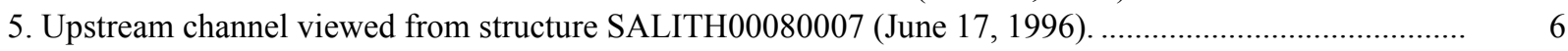

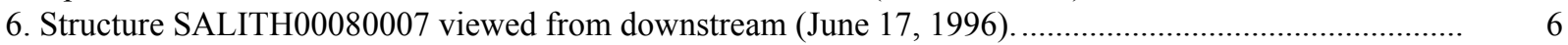

7. Water-surface profiles for the 100- and 500-year discharges at structure

SALITH00080007 on Town Highway 8, crossing the Middlebury River,

Salisbury, Vermont.

8. Scour elevations for the 100- and 500-year discharges at structure

SALITH00080007 on Town Highway 8, crossing the Middlebury River,

Salisbury, Vermont.

\section{TABLES}

1. Remaining footing/pile depth at abutments for the 100-year discharge at structure

SALITH00080007 on Town Highway 8, crossing the Middlebury River,

Salisbury, Vermont .....

2. Remaining footing/pile depth at abutments for the 500-year discharge at structure

SALITH00080007 on Town Highway 8, crossing the Middlebury River,

Salisbury, Vermont

5




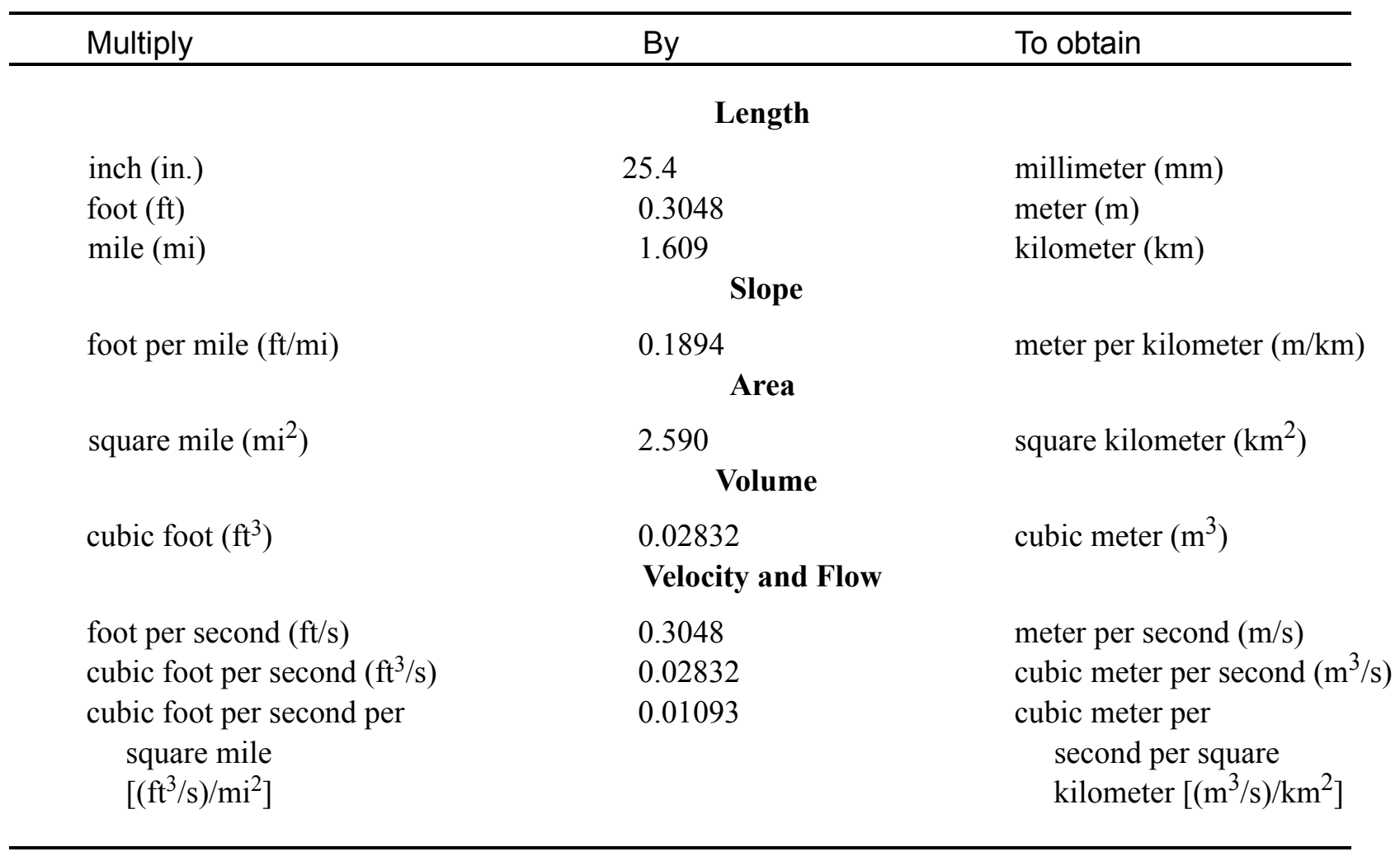

\section{OTHER ABBREVIATIONS}

$\begin{array}{lrlr}\mathrm{BF} & \text { bank full } & \text { LWW } & \text { left wingwall } \\ \mathrm{cfs} & \text { cubic feet per second } & \text { MC } & \text { main channel } \\ \mathrm{D}_{50} & \text { median diameter of bed material } & \text { RAB } & \text { right abutment } \\ \mathrm{DS} & \text { downstream } & \text { RABUT } & \text { face of right abutment } \\ \mathrm{elev} & \text { elevation } & \text { RB } & \text { right bank } \\ \mathrm{f} / \mathrm{p} & \text { flood plain } & \text { ROB } & \text { right overbank } \\ \mathrm{ft}^{2} & \text { square feet } & \text { RWW } & \text { right wingwall } \\ \mathrm{ft} / \mathrm{ft} & \text { feet per foot } & \text { TH } & \text { town highway } \\ \mathrm{JCT} & \text { junction } & \text { UB } & \text { under bridge } \\ \mathrm{LAB} & \text { left abutment } & \text { US } & \text { upstream } \\ \mathrm{LABUT} & \text { face of left abutment } & \text { USGS } & \text { United States Geological Survey } \\ \mathrm{LB} & \text { left bank } & \text { VTAOT Vermont Agency of Transportation } \\ \mathrm{LOB} & \text { left overbank } & \text { WSPRO } & \text { water-surface profile model }\end{array}$

In this report, the words "right" and "left" refer to directions that would be reported by an observer facing downstream. Sea level: In this report, "sea level" refers to the National Geodetic Vertical Datum of 1929-- a geodetic datum derived from a general adjustment of the first-order level nets of the United States and Canada, formerly called Sea Level Datum of 1929.

In the appendices, the above abbreviations may be combined. For example, USLB would represent upstream left bank. 


\title{
LEVEL II SCOUR ANALYSIS FOR BRIDGE 7 (SALITH00080007) ON TOWN HIGHWAY 8, CROSSING THE MIDDLEBURY RIVER, SALISBURY, VERMONT
}

\author{
By Erick M. Boehmler and Laura Medalie
}

\section{INTRODUCTION AND SUMMARY OF RESULTS}

This report provides the results of a detailed Level II analysis of scour potential at structure SALITH00080007 on Town Highway 8 crossing the Middlebury River, Salisbury, Vermont (figures 1-8). A Level II study is a basic engineering analysis of the site, including a quantitative analysis of stream stability and scour (U.S. Department of Transportation, 1993). Results of a Level I scour investigation also are included in Appendix E of this report. A Level I investigation provides a qualitative geomorphic characterization of the study site. Information on the bridge, gleaned from Vermont Agency of Transportation (VTAOT) files, was compiled prior to conducting Level I and Level II analyses and is found in appendix D.

The site is in the Champlain section of the Saint Lawrence Valley physiographic province in west-central Vermont. However, most of the watershed is situated in the Green Mountain section of the New England province. The 62.4- $\mathrm{mi}^{2}$ drainage area is in a predominantly rural and forested basin. In the vicinity of the study site, the surface cover is pasture upstream of the bridge. There are row-crops on the downstream right overbank and forest on the downstream left overbank.

In the study area, the Middlebury River has an meandering channel with a slope of approximately $0.0009 \mathrm{ft} / \mathrm{ft}$, an average channel top width of 84 feet and an average bank height of 7 feet. The channel bed material ranges from sand to cobbles with a median grain size $\left(\mathrm{D}_{50}\right)$ of $0.974 \mathrm{~mm}(0.00319 \mathrm{ft})$. The geomorphic assessment at the time of the Level I and Level II site visit on June 17, 1996, indicated that the reach was laterally unstable. The meandering configuration of the channel, cut-banks with block failure of the bank material, and the fine size of the bed and bank material suggest the potential for lateral movement of the channel is significant at this site.

The Town Highway 8 crossing of the Middlebury River is a 60-ft-long, two-lane bridge consisting of one 57-foot steel-beam span (Vermont Agency of Transportation, written communication, December 15, 1995). The opening length of the structure parallel to the bridge face is 54.2 feet. The bridge is supported by vertical, concrete abutments with sloping wingwalls and embankments. The channel is skewed approximately 25 degrees to the opening while the opening-skew-to-roadway is 10 degrees. 
A scour hole, 4 feet deeper than the mean thalweg depth, was observed along the left bank side of the channel upstream of the site during the Level I assessment. Bedrock is exposed along the left bank upstream adjacent to the scour hole. The scour protection measures at this site were type-1 (less than 12 inches diameter) and type-2 (less than 36 inches diameter) stone fill. Type-1 stone fill was noted on the upstream left bank, and the upstream and downstream right wingwalls. Type-2 stone fill was found on the upstream left wingwall, the left abutment, and the downstream right bank. Additional details describing conditions at the site are included in the Level II Summary and appendices D and E.

Scour depths and recommended rock rip-rap sizes were computed using the general guidelines described in Hydraulic Engineering Circular 18 (Richardson and others, 1995) for the 100- and 500-year discharges. In addition, the incipient roadway-overtopping discharge was determined and analyzed as another potential worst-case scour scenario. Total scour at a highway crossing is comprised of three components: 1) long-term streambed degradation; 2) contraction scour (due to accelerated flow caused by a reduction in flow area at a bridge) and; 3 ) local scour (caused by accelerated flow around piers and abutments). Total scour is the sum of the three components. Equations are available to compute depths for contraction and local scour and a summary of the results of these computations follows.

Contraction scour for all modelled flows ranged from 5.7 to 13.5 feet. The worst-case contraction scour occurred at the 100-year discharge. Abutment scour ranged from 8.3 to 18.8 feet. The worst-case abutment scour occurred at the 500 -year discharge. Additional information on scour depths and depths to armoring are included in the section titled "Scour Results". Scoured-streambed elevations, based on the calculated scour depths, are presented in tables 1 and 2. A cross-section of the scour computed at the bridge is presented in figure 8. Scour depths were calculated assuming an infinite depth of erosive material and a homogeneous particle-size distribution.

It is generally accepted that the Froehlich equation (abutment scour) gives "excessively conservative estimates of scour depths" (Richardson and others, 1995, p. 47). Usually, computed scour depths are evaluated in combination with other information including (but not limited to) historical performance during flood events, the geomorphic stability assessment, existing scour protection measures, and the results of the hydraulic analyses. Therefore, scour depths adopted by VTAOT may differ from the computed values documented herein. 


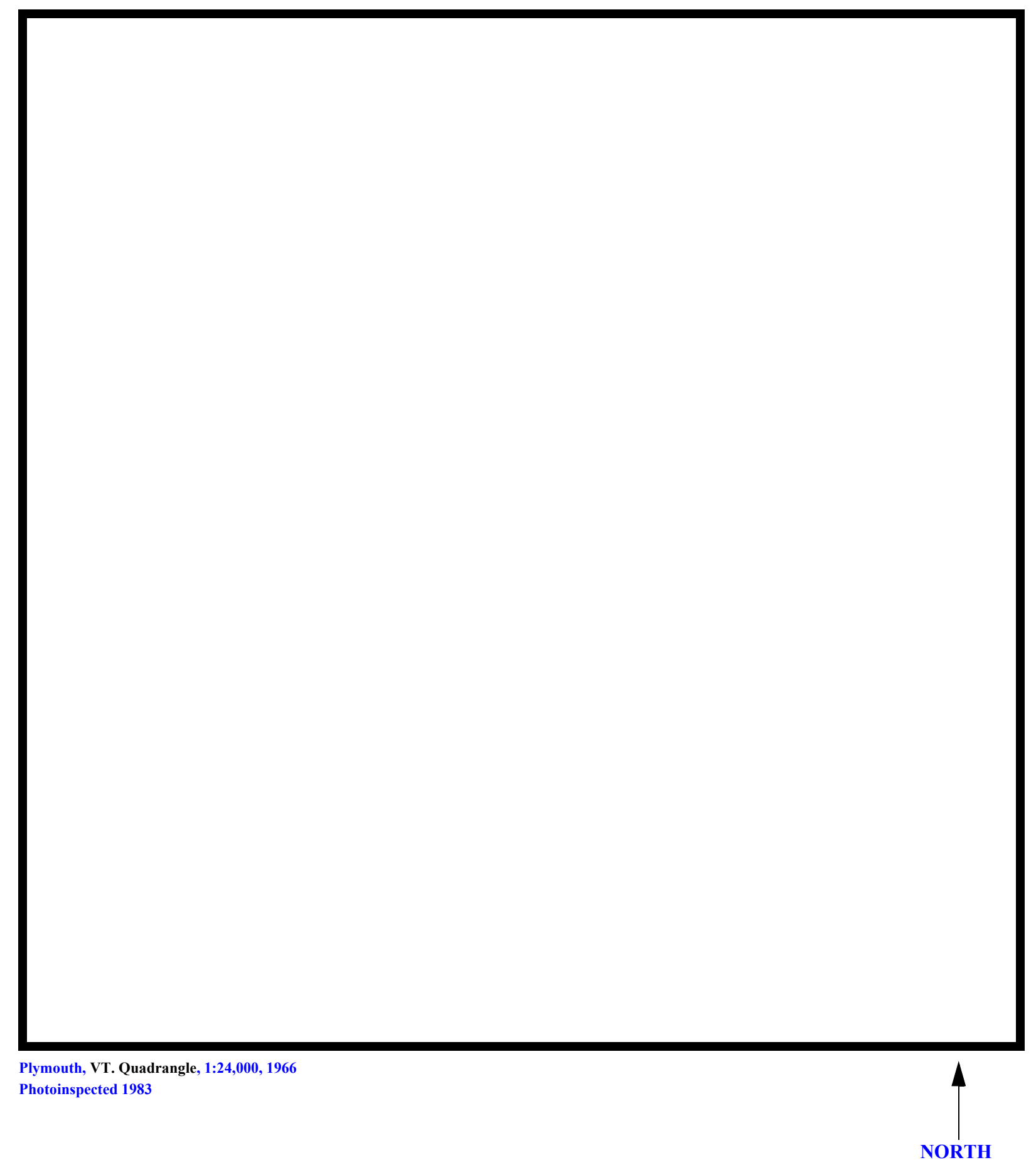

Figure 1. Location of study area on USGS 1:24,000 scale map. 
Figure 2. Location of study area on Vermont Agency of Transportation town highway map. 

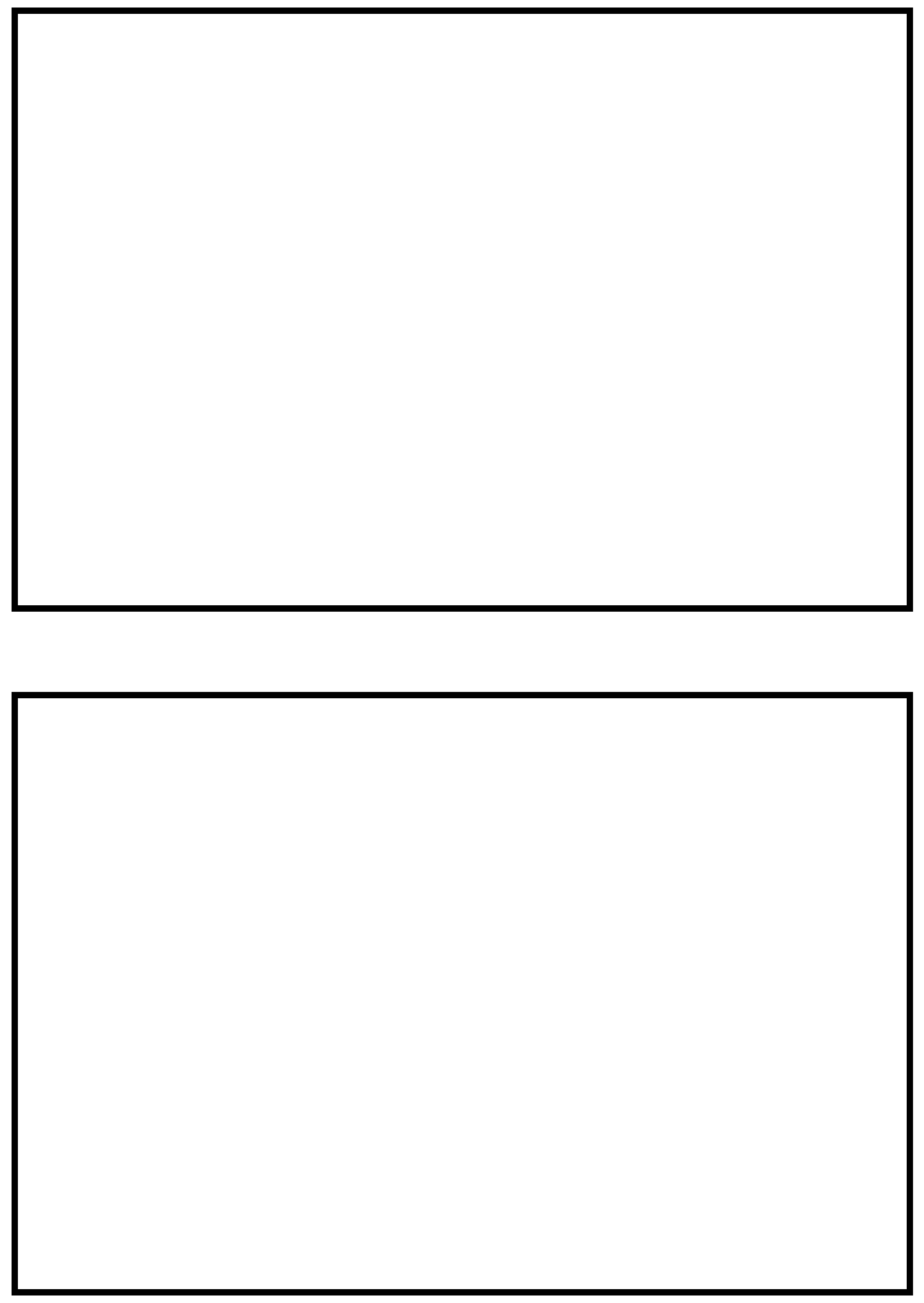

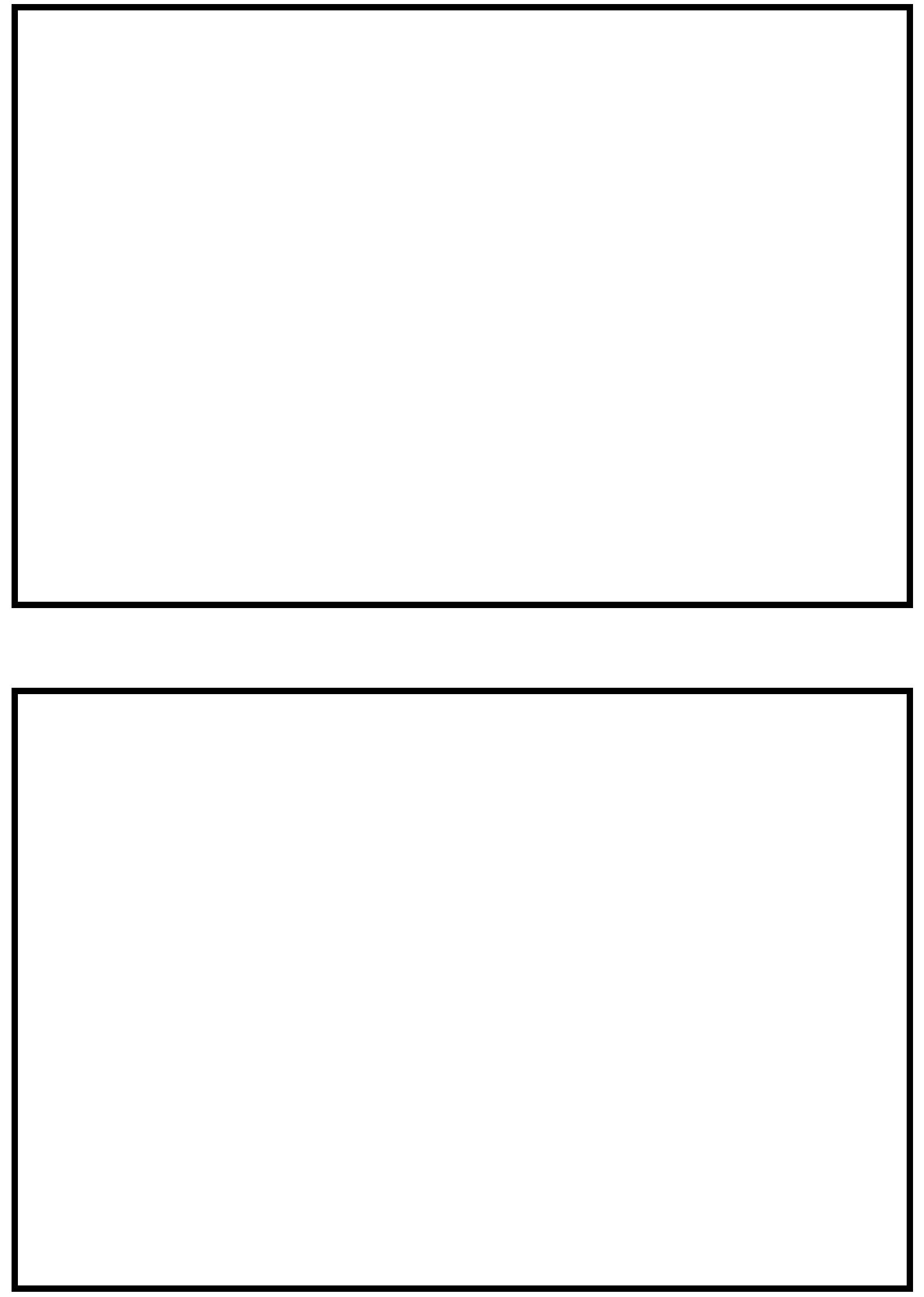


\section{LEVEL II SUMMARY}

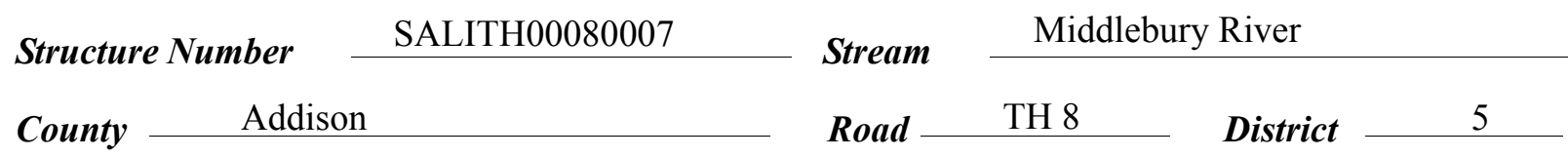

\section{Description of Bridge}

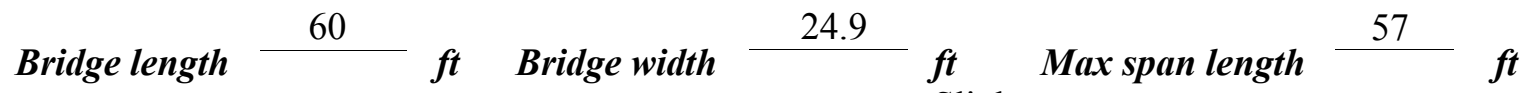
Alignment of bridge to road (on curve or straight)

Abutment type Vertical, concrete

Stone fill on abutment? Yes

\section{Embankment type} Slight curve

\section{Sloping}

nocomintinu af otons fill

$6 / 17 / 96$

of the left abutment and type- 1 was noted at the upstream end of the upstream right wingwall and along the entire downstream right wingwall.

The abutments and wingwalls are concrete.

$\cdots$

\section{Is bridge skewed to flood flow according to Yes ' survey? Angle}

There is a severe channel bend in the upstream reach, The scour hole has developed in the location where the flow impacts the bedrock exposure on the upstream left bank.

Debris accumulation on bridge at time of Level I or Level II site visit:

Date of insnortion $6 / 17 / 96$

Level I

$$
6 / 17 / 96
$$

\section{Yes}

25

\section{Percent of rhammol blocked inortzontaty}

$$
0
$$

Level II

Moderate. There are a few trees on the banks of this meandering, laterally unstable channel.

Potential for debris

None evident on 6/17/96.

Doscriho anv fonturos noar ar at tho hridoo that mav, affort flow, (includo ahsorvation dato) 


\section{Description of the Geomorphic Setting}

General topography The channel is located in a wide flood plain with mild to moderately sloping valley walls on both sides.

Geomorphic conditions at bridge site: downstream (DS), upstream (US)

Date of inspection $\quad 6 / 17 / 96$

DS left: $\quad$ Moderately sloping channel bank to an irregular overbank.

DS right: $\quad$ Moderately sloping channel bank to an irregular flood plain.

US left: $\quad$ Moderately sloping channel bank and valley wall.

US right: $\quad$ Moderately sloping channel bank to an irregular flood plain.

\section{Description of the Channel}

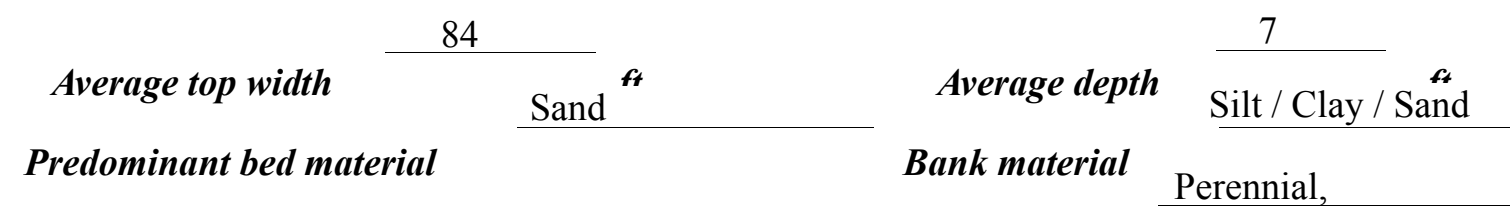

meandering, and wider at bends with semi-alluvial channel boundaries and narrow bars.

$6 / 17 / 96$

Vegetative co 1 Trees, shrubs, and brush.

DS left: $\quad$ Trees, shrubs, and brush.

DS right: $\quad$ Trees, shrubs, and brush.

US left: $\quad$ Grass and brush with a few trees and shrubs.

US right: $\quad$ No

Do banks appear stable? The channel meanders and there is fine size bank and bed material

through the reach. There was block failure of bank material at cut-banks evident upstream of this
date of observatton. site at the time of the assessment.

None evident on

6/17/96.

Describe any obstructions in channel and date of observation. 


\section{Hydrology}

Drainage area $\quad 62.4 \quad \mathrm{mi}^{2}$

Percentage of drainage area in physiographic provinces: (approximate)

Physiographic province/section Saint Lawrence Valley / Champlain

New England / Green Mountain

Is drainage area considered rural or urban?
Percent of drainage area

5

95

Rural

Describe any significant urbanization:

Is there a USGS gage on the stream of interest?

No

USGS gage description

USGS gage number

Gage drainage area $\mathrm{mi}^{2}$ $m i^{2}$ No

Is there a lake',

... . . . n . . , , . . 


\section{Description of the Water-Surface Profile Model (WSPRO) Analysis}

Datum for WSPRO analysis (USGS survey, sea level, VTAOT plans)

USGS survey

Datum tie between USGS survey and VTAOT plans

Subtract 12.1 feet from the USGS

arbitrary survey datum to obtain the VTAOT plans' datum.

Description of reference marks used to determine USGS datum. $\quad$ RM1 is a VTAOT

metallic disk set in the top of the concrete upstream left wingwall (elev. 510.84 feet, arbitrary

survey datum). RM2 is a nail in the second power pole to the right from the bridge (elev. 502.56

feet, arbitrary survey datum). RM3 is a chiseled X on top of the downstream end of the right

abutment (elev. 508.38 feet, arbitrary survey datum).

\section{Cross-Sections Used in WSPRO Analysis}

\begin{tabular}{cccl}
\hline${ }^{\text {ICross-section }}$ & $\begin{array}{c}\text { Section } \\
\text { Reference } \\
\text { Distance } \\
(\text { SRD) in feet }\end{array}$ & $\begin{array}{c}{ }^{2} \text { Cross-section } \\
\text { development }\end{array}$ & \multicolumn{1}{c}{ Comments } \\
\hline EXITX & -88 & 1 & Exit section \\
FULLV & 0 & 5 & $\begin{array}{l}\text { Downstream Full-valley sec- } \\
\text { tion (BRIDG channel and }\end{array}$ \\
BRIDG & 0 & 1 & $\begin{array}{l}\text { EXITX overbank) } \\
\text { RDWAY }\end{array}$ \\
APPRO & 15 & 1 & Road Grade section \\
\hline
\end{tabular}

${ }^{1}$ For location of cross-sections see plan-view sketch included with Level I field form, Appendix E. For more detail on how cross-sections were developed see WSPRO input file. 


\section{Data and Assumptions Used in WSPRO Model}

Hydraulic analyses of the reach were done by use of the Federal Highway Administration's WSPRO step-backwater computer program (Shearman and others, 1986, and Shearman, 1990). The analyses reported herein reflect conditions existing at the site at the time of the study. Furthermore, in the development of the model it was necessary to assume no accumulation of debris or ice at the site. Results of the hydraulic model are presented in the Bridge Hydraulic Summary, appendix B, and figure 7.

Channel roughness factors (Manning's “ $n$ ”) used in the hydraulic model were estimated using field inspections at each cross section following the general guidelines described by Arcement and Schneider (1989). Final adjustments to the values were made during the modelling of the reach. Channel " $n$ " values for the reach ranged from 0.037 to 0.057 , and overbank " $n$ " values ranged from 0.042 to 0.075 .

Normal depth at the exit section (EXITX) was assumed as the starting water surface. This depth was computed by use of the slope-conveyance method outlined in the user's manual for WSPRO (Shearman, 1990). The slope used was $0.00088 \mathrm{ft} / \mathrm{ft}$, which was estimated from the topographic map (U.S. Geological Survey, 1943).

The approach section (APPRO) was surveyed one bridge length upstream of the upstream face as recommended by Shearman and others (1986). This location provides a consistent method for determining scour variables. 


\section{Bridge Hydraulics Summary}

$\begin{array}{llll}\text { Average bridge embankment elevation } & 509.8 & f t \\ \text { Average low steel elevation } & 506.2 & \boldsymbol{f t}\end{array}$

100-year discharge $\quad 7,000 \quad \mathrm{ft}^{3} / \mathrm{s}$

Water-surface elevation in bridge opening $\quad 505.1 \quad f t$

Road overtopping? ___ Yes Discharge over road __ $2090 \quad \mathrm{ft}^{3} / \mathrm{s}$

\begin{tabular}{llll} 
Area of flow in bridge opening & $734 \quad \mathrm{ft}^{2}$ \\
\cline { 2 - 3 } Average velocity in bridge opening & 6.7 & $\mathrm{ft} / \mathrm{s}$
\end{tabular}

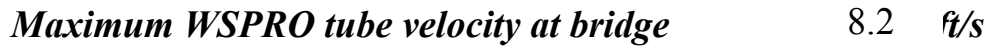

Water-surface elevation at Approach section with bridge

Water-surface elevation at Approach section without bridge

506.1

Amount of backwater caused by bridge

1.0 it

500-year discharge $\quad 9,800 \quad \mathrm{ft}^{3} / \mathrm{s}$

Water-surface elevation in bridge opening

$506.5 f t$

Road overtopping? ___ Yes Discharge over road __ 5,500 $\mathrm{ft}^{3} / \mathrm{s}$

Area of flow in bridge opening $\quad 784 \quad \mathrm{ft}^{2}$

Average velocity in bridge opening $5.5 \mathrm{ft} / \mathrm{s}$

Maximum WSPRO tube velocity at bridge 7.9 _'s

Water-surface elevation at Approach section with bridge

Water-surface elevation at Approach section without bridge

Amount of backwater caused by bridge 1.0 , $t$

507.3

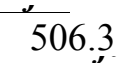

Incipient overtopping discharge $\quad 4,250 \quad \mathrm{ft}^{3} / \mathrm{s}$

Water-surface elevation in bridge opening $\quad 503.0 \quad t$

Area of flow in bridge opening

$621 \quad \mathrm{ft}^{2}$

Average velocity in bridge opening

6.8 $f t / s$

Maximum WSPRO tube velocity at bridge $\quad 8.3 \mathrm{ft} / \mathrm{s}$

Water-surface elevation at Approach section with bridge

Water-surface elevation at Approach section without bridge

504.0

Amount of backwater caused by bridge

0.5 . $t$ 


\section{Scour Analysis Summary}

\section{Special Conditions or Assumptions Made in Scour Analysis}

Scour depths were computed using the general guidelines described in Hydraulic Engineering Circular 18 (Richardson and Davis, 1995). Scour depths were calculated assuming an infinite depth of erosive material and a homogeneous particle-size distribution. However, bedrock was exposed at the surface along the left bank side of the channel and may limit the depth of scour at this site. The results of the scour analyses for the 100- and 500year discharges are presented in tables 1 and 2 and the 100-year scour depths are shown graphically in figure 8 . The scour depths for the 500 -year event were less than those for the 100-year event and thus do not appear in figure 8.

Contraction scour for each modeled discharge was computed by use of the Laursen live-bed contraction scour equation (Richardson and Davis, 1995, p. 30, equation 17). Results from this contraction scour analysis are shown in tables 1 and 2 and figure 8 . At this site, the incipient motion velocity was very close to the critical velocity. Therefore, contraction scour also was computed by use of the Laursen clear-water contraction scour equation (Richardson and Davis, 1995, p. 32, equation 20). Results from this analysis are provided in appendix $\mathrm{F}$.

Abutment scour for the left abutment was computed by use of the Froehlich equation (Richardson and Davis, 1995, p. 48, equation 28). Variables for the Froehlich equation include the Froude number of the flow approaching the embankments, the length of the embankment blocking flow, and the depth of flow approaching the embankment less any roadway overtopping.

Scour at the right abutment was computed by use of the HIRE equation (Richardson and Davis, 1995, p. 49, equation 29) because the HIRE equation is recommended when the length to depth ratio of the embankment blocking flow exceeds 25 . The variables used by the HIRE abutment-scour equation are defined the same as those defined for the Froehlich abutment-scour equation. 


\section{Scour Results}

100-yr discharge 500-yr discharge

Incipient

overtopping

Contraction scour:

(Scour depths in feet)

Main channel

Live-bed scour

13.5

Clear-water scour

Depth to armoring

Left overbank

Right overbank

Local scour:

Abutment scour

16.0

18.8

13.4

Left abutment

11.2

$12.7-$

8.3-

Right abutment

Pier scour

Pier 1

Pier 2

Pier 3

Abutments:

Left abutment

Right abutment

Piers:

Pier 1

Pier 2

\section{Riprap Sizing}

Incipient overtopping 100-yr discharge 500-yrdischarge discharge ( $D_{50}$ in feet)

1.1

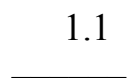

$--$

$--$

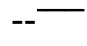

0.8

0.8

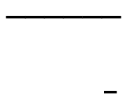

$-{ }^{-}$
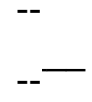

1.1

1.1 


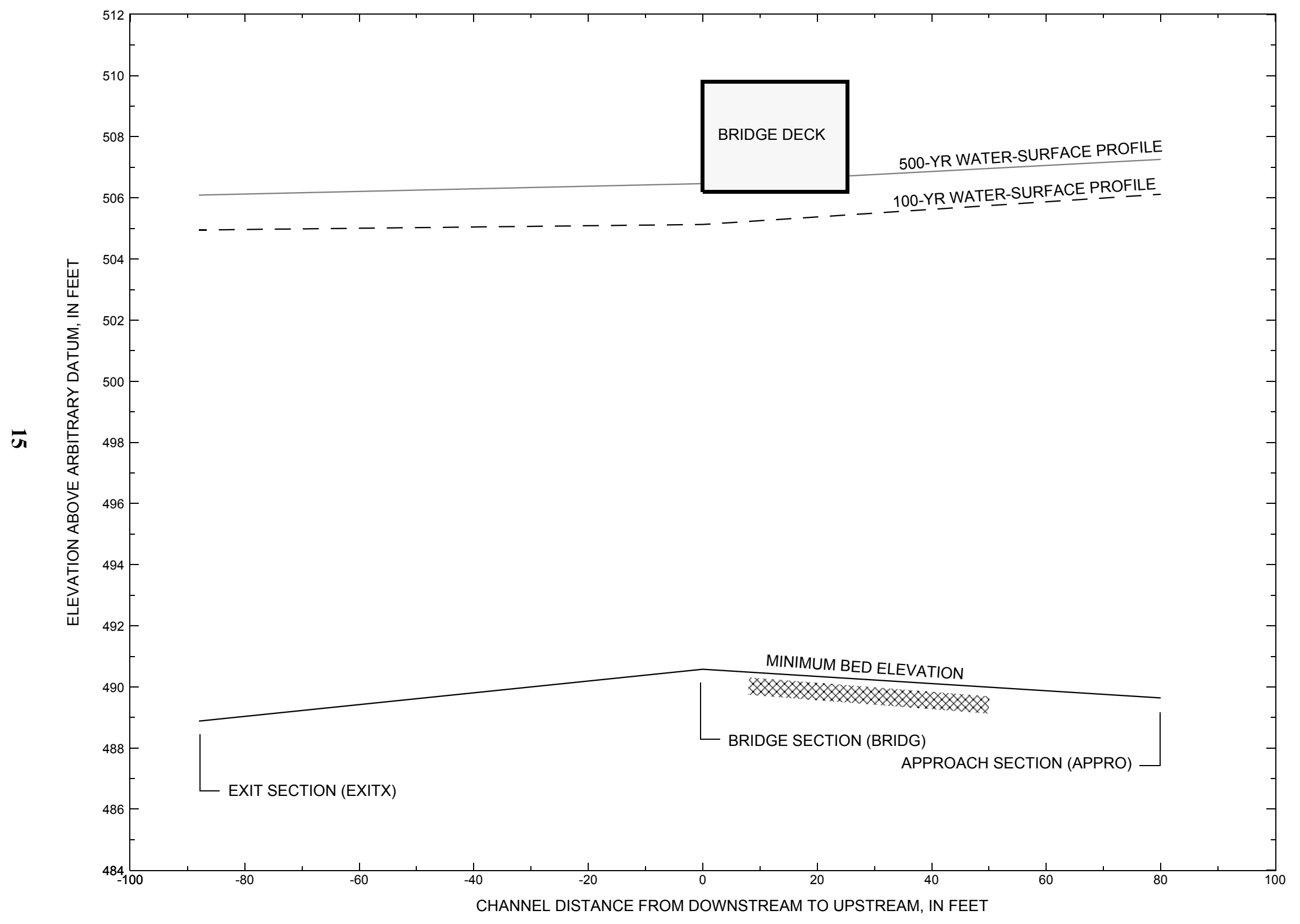

Figure 7. Water-surface profiles for the 100- and 500-year discharges at structure SALITH00080007 on Town Highway 8, crossing the Middlebury River, Salisbury, Vermont. 


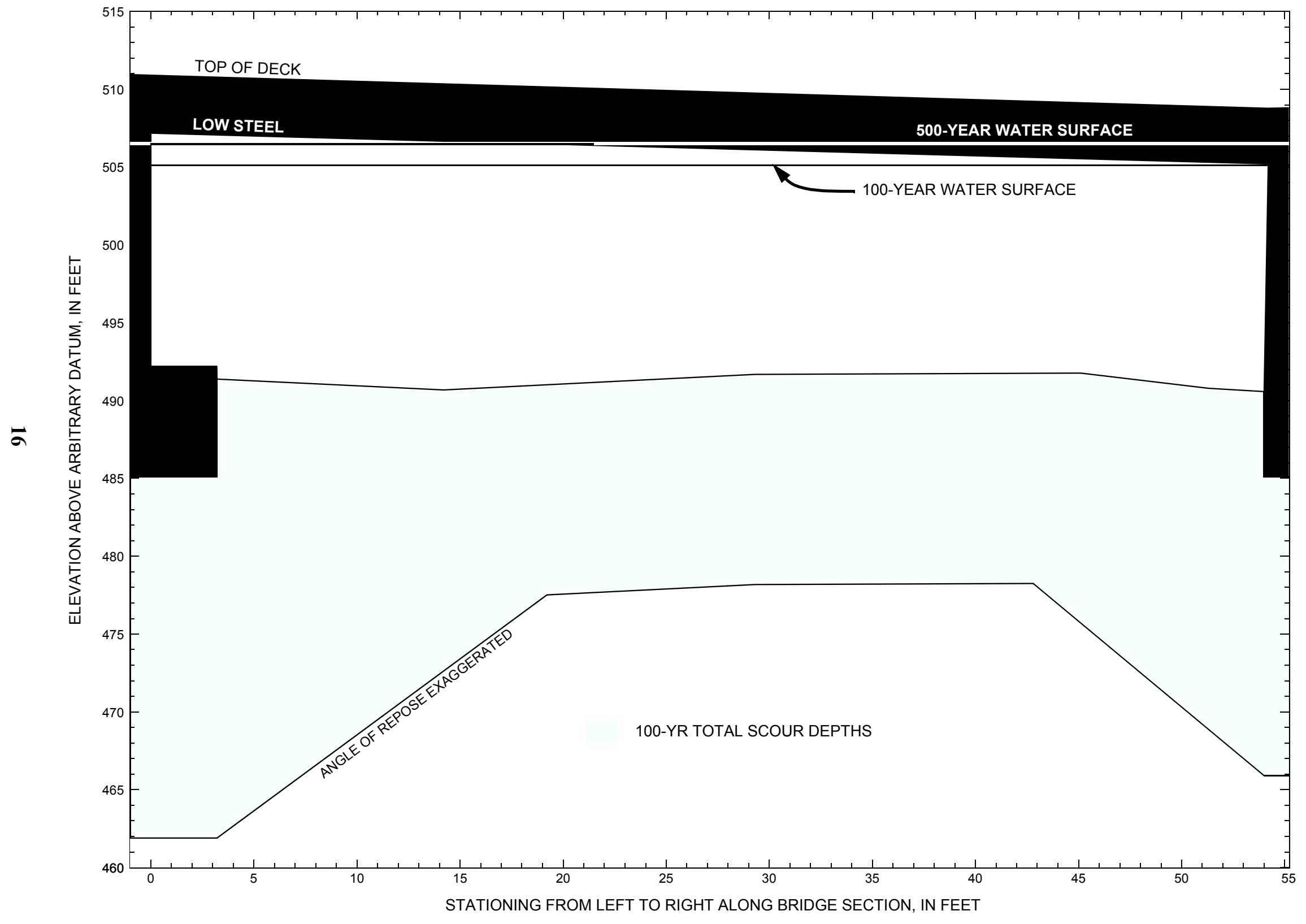

Figure 8. Scour elevations for the 100-year discharge at structure SALITH00080007 on Town Highway 8, crossing the Middlebury River, Salisbury, Vermont. 
Table 1. Remaining footing/pile depth at abutments for the 100-year discharge at structure SALITH00080007 on Town Highway 8, crossing the Middlebury River, Salisbury, Vermont.

[VTAOT, Vermont Agency of Transportation; --,no data]

\begin{tabular}{|c|c|c|c|c|c|c|c|c|c|c|c|}
\hline Description & Station $^{1}$ & $\begin{array}{c}\text { VTAOT } \\
\text { bridge seat } \\
\text { elevation } \\
\text { (feet) }\end{array}$ & $\begin{array}{l}\text { Surveyed } \\
\text { minimum } \\
\text { low-chord } \\
\text { elevation } \\
\quad \text { (feet) }\end{array}$ & $\begin{array}{c}\text { Bottom of } \\
\text { footing/pile } \\
\text { elevation }^{2} \\
\text { (feet) }\end{array}$ & $\begin{array}{l}\text { Channel } \\
\text { elevation at } \\
\text { abutment/ } \\
\text { pier }^{2} \\
\text { (feet) }\end{array}$ & $\begin{array}{l}\text { Contraction } \\
\text { scour depth } \\
\text { (feet) }\end{array}$ & $\begin{array}{l}\text { Abutment } \\
\text { scour } \\
\text { depth } \\
\text { (feet) }\end{array}$ & $\begin{array}{l}\text { Pier } \\
\text { scour } \\
\text { depth } \\
\text { (feet) }\end{array}$ & $\begin{array}{l}\text { Depth of } \\
\text { total scour } \\
\text { (feet) }\end{array}$ & $\begin{array}{c}\text { Elevation of } \\
\text { scour }^{2} \\
\text { (feet) }\end{array}$ & $\begin{array}{c}\text { Remaining } \\
\text { footing/pile } \\
\text { depth } \\
\text { (feet) }\end{array}$ \\
\hline \multicolumn{12}{|c|}{100 -year discharge is 7,000 cubic-feet per second } \\
\hline Left abutment & 0.0 & 494.9 & 507.2 & 485.1 & 491.4 & 13.5 & 16.0 & -- & 29.5 & 461.9 & -23.2 \\
\hline Right abutment & 54.2 & 492.7 & 505.2 & 485.1 & 490.6 & 13.5 & 11.2 & -- & 24.7 & 465.9 & -19.2 \\
\hline
\end{tabular}

1.Measured along the face of the most constricting side of the bridge.

2.Arbitrary datum for this study.

Table 2. Remaining footing/pile depth at abutments for the 500-year discharge at structure SALITH00080007 on Town Highway 8, crossing the Middlebury River, Salisbury, Vermont.

[VTAOT, Vermont Agency of Transportation; --, no data]

\begin{tabular}{|c|c|c|c|c|c|c|c|c|c|c|c|}
\hline Description & Station $^{1}$ & $\begin{array}{c}\text { VTAOT } \\
\text { bridge seat } \\
\text { elevation } \\
\text { (feet) }\end{array}$ & $\begin{array}{l}\text { Surveyed } \\
\text { minimum } \\
\text { low-chord } \\
\text { elevation } \\
\quad \text { (feet) }\end{array}$ & $\begin{array}{c}\text { Bottom of } \\
\text { footing/pile } \\
\text { elevation }{ }^{2} \\
\text { (feet) }\end{array}$ & $\begin{array}{c}\text { Channel } \\
\text { elevation at } \\
\text { abutment/ } \\
\text { pier }^{2} \\
\text { (feet) }\end{array}$ & $\begin{array}{l}\text { Contraction } \\
\text { scour depth } \\
\text { (feet) }\end{array}$ & $\begin{array}{l}\text { Abutment } \\
\text { scour } \\
\text { depth } \\
\text { (feet) }\end{array}$ & $\begin{array}{l}\text { Pier } \\
\text { scour } \\
\text { depth } \\
\text { (feet) }\end{array}$ & $\begin{array}{l}\text { Depth of } \\
\text { total scour } \\
\text { (feet) }\end{array}$ & $\begin{array}{c}\text { Elevation of } \\
\text { scour }^{2} \\
\text { (feet) }\end{array}$ & $\begin{array}{c}\text { Remaining } \\
\text { footing/pile } \\
\text { depth } \\
\text { (feet) }\end{array}$ \\
\hline \multicolumn{12}{|c|}{500 -year discharge is 9,800 cubic-feet per second } \\
\hline Left abutment & 0.0 & 494.9 & 507.2 & 485.1 & 491.4 & 5.7 & 18.8 & -- & 24.5 & 466.9 & -18.2 \\
\hline Right abutment & 54.2 & 492.7 & 505.2 & 485.1 & 490.6 & 5.7 & 12.7 & -- & 18.4 & 472.2 & -12.9 \\
\hline
\end{tabular}

1.Measured along the face of the most constricting side of the bridge.

2.Arbitrary datum for this study. 


\section{SELECTED REFERENCES}

Arcement, G.J., Jr., and Schneider, V.R., 1989, Guide for selecting Manning's roughness coefficients for natural channels and flood plains: U.S. Geological Survey Water-Supply Paper 2339, 38 p.

Barnes, H.H., Jr., 1967, Roughness characteristics of natural channels: U.S. Geological Survey Water-Supply Paper 1849,213 p.

Benson, M. A., 1962, Factors Influencing the Occurrence of Floods in a Humid Region of Diverse Terrain: U.S. Geological Survey WaterSupply Paper 1580-B, 64 p.

Brown, S.A. and Clyde, E.S., 1989, Design of riprap revetment: Federal Highway Administration Hydraulic Engineering Circular No. 11, Publication FHWA-IP-89-016, 156 p.

Federal Highway Administration, 1983, Runoff estimates for small watersheds and development of sound design: Federal Highway Administration Report FHWA-RD-77-158.

Federal Highway Administration, 1993, Stream Stability and Scour at Highway Bridges: Participant Workbook: Federal Highway Administration Report FHWA-HI-91-011.

Froehlich, D.C., 1989, Local scour at bridge abutments in Ports, M.A., ed., Hydraulic Engineering--Proceedings of the 1989 National Conference on Hydraulic Engineering: New York, American Society of Civil Engineers, p. 13-18.

Hayes, D.C.,1993, Site selection and collection of bridge-scour data in Delaware, Maryland, and Virginia: U.S. Geological Survey WaterResources Investigation Report 93-4017, 23 p.

Interagency Advisory Committee on Water Data, 1982, Guidelines for determining flood flow frequency: U.S. Geological Survey, Bulletin 17B of the Hydrology Subcommittee, $190 \mathrm{p}$.

Johnson, C.G. and Tasker, G.D.,1974, Progress report on flood magnitude and frequency of Vermont streams: U.S. Geological Survey OpenFile Report 74-130, 37 p.

Lagasse, P.F., Schall, J.D., Johnson, F., Richardson, E.V., Chang, F., 1995, Stream Stability at Highway Structures: Federal Highway Administration Hydraulic Engineering Circular No. 20, Publication FHWA-IP-90-014, 144 p.

Laursen, E.M., 1960, Scour at bridge crossings: Journal of the Hydraulics Division, American Society of Civil Engineers, v. 86, no. HY2, p. 39-53.

Potter, W. D., 1957a, Peak rates of runoff in the Adirondack, White Mountains, and Maine woods area, Bureau of Public Roads

Potter, W. D., 1957b, Peak rates of runoff in the New England Hill and Lowland area, Bureau of Public Roads

Richardson, E.V. and Davis, S.R., 1995, Evaluating scour at bridges: Federal Highway Administration Hydraulic Engineering Circular No. 18, Publication FHWA-IP-90-017, 204 p.

Richardson, E.V., Simons, D.B., and Julien, P.Y., 1990, Highways in the river environment: Federal Highway Administration Publication FHWA-HI-90-016.

Ritter, D.F., 1984, Process Geomorphology: W.C. Brown Co., Debuque, Iowa, 603 p.

Shearman, J.O., 1990, User's manual for WSPRO--a computer model for water surface profile computations: Federal Highway Administration Publication FHWA-IP-89-027, 187 p.

Shearman, J.O., Kirby, W.H., Schneider, V.R., and Flippo, H.N., 1986, Bridge waterways analysis model; research report: Federal Highway Administration Publication FHWA-RD-86-108, 112 p.

Talbot, A.N., 1887, The determination of water-way for bridges and culverts.

U.S. Department of Transportation, 1993, Stream stability and scour at highway bridges, Participant Workbook: Federal Highway Administration Publication FHWA HI-91-011.

U.S. Geological Survey, 1943, Cornwall, Vermont 7.5 Minute Series quadrangle map: U.S. Geological Survey Topographic Maps; Photoinspected 1983; Contour interval, 20 feet; Scale 1:24,000.

U.S. Geological Survey, 1944, East Middlebury, Vermont 7.5 Minute Series Quadrangle Map: U.S. Geological Survey p Topographic Maps; Photorevised, 1972; Contour Interval, 20 feet, Scale, 1:24,000. 


\section{APPENDIX A: \\ WSPRO INPUT FILE}




\section{WSPRO INPUT FILE}

GR

GR

GR

GR

GR

GR

GR

GR

GR

GR

$\mathrm{N}$

SA

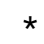

*

BR

GR

GR

GR

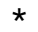

CD

$\mathrm{N}$

*

$\star$

$\mathrm{XR}$

GR

GR

GR

*

AS

GR

GR

GR

GR

GR

*

*

$\mathrm{N}$

SA
U.S. Geological Survey WSPRO Input File sali007.wsp Hydraulic analysis for structure SALITH00080007 Date: 27-JUN-97 Town Highway 8 Crossing the Middlebury River, Salisbury, VT

EMB

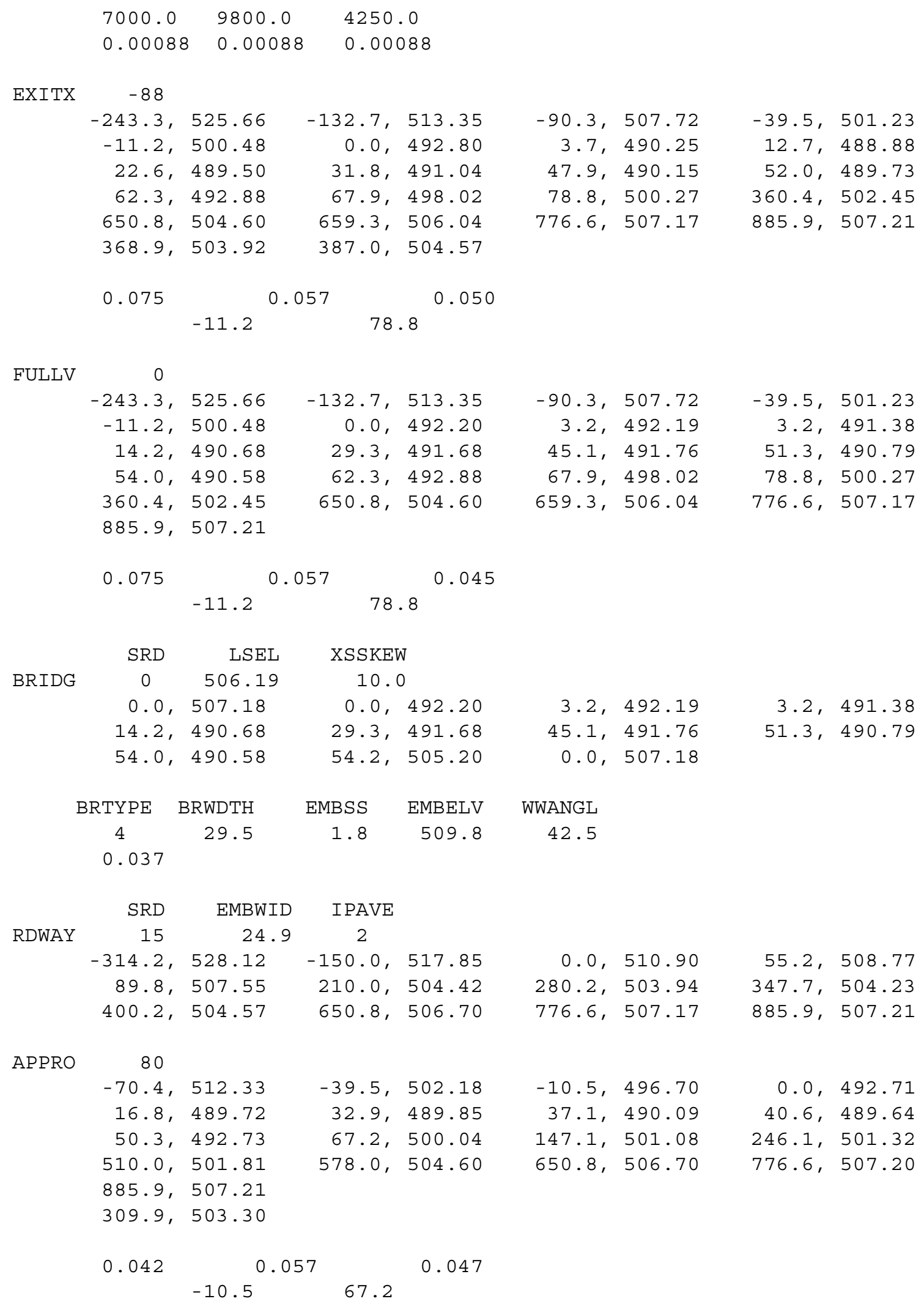


WSPRO INPUT FILE (continued)

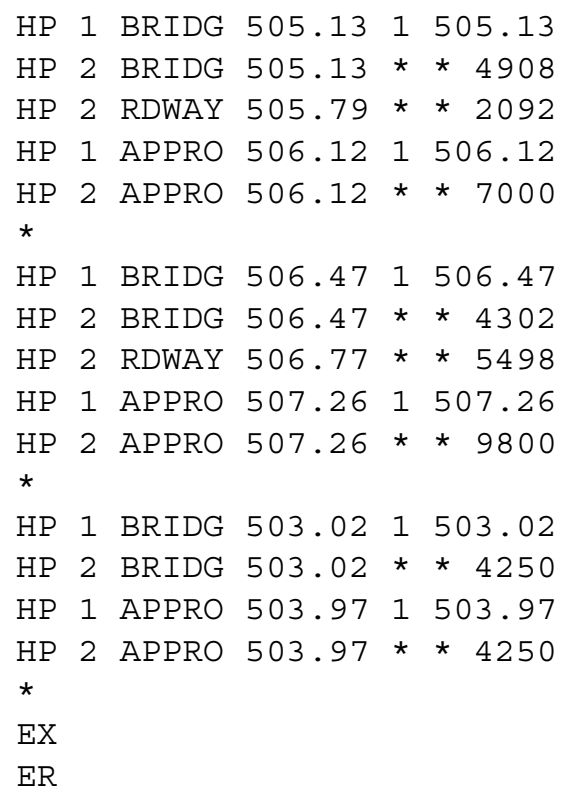




\section{APPENDIX B: \\ WSPRO OUTPUT FILE}


WSPRO OUTPUT FILE

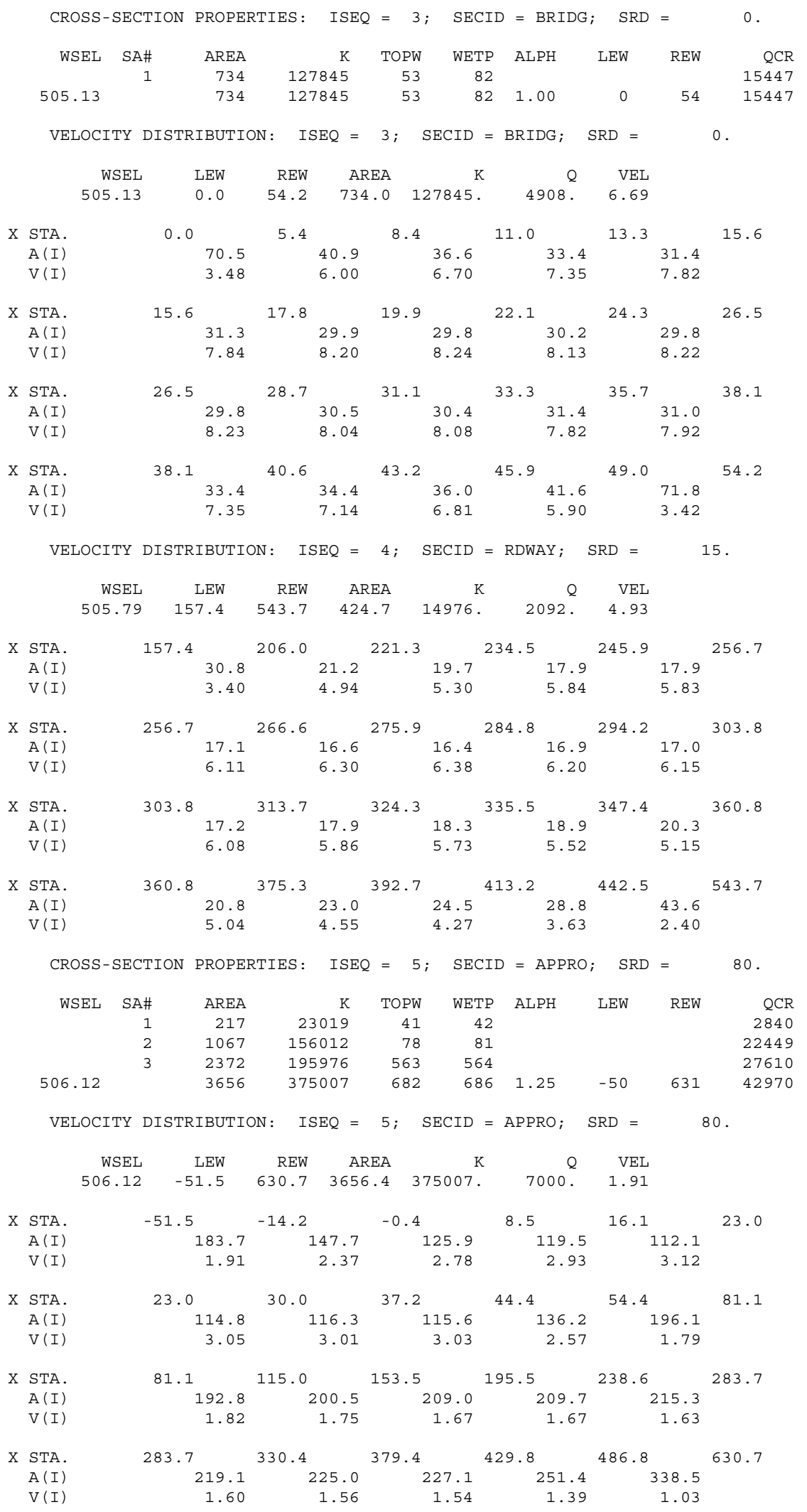


WSPRO OUTPUT FILE (continued)

\author{
U.S. Geological Survey WSPRO Input File salio07.wsp \\ Hydraulic analysis for structure SALITH00080007 Date: 27-JUN-97 \\ Town Highway 8 Crossing the Middlebury River, Salisbury, VT EMB \\ *** RUN DATE \& TIME: 11-24-97 11:29 \\ CROSS-SECTION PROPERTIES: $\quad$ ISEQ $=3 ;$ SECID $=$ BRIDG $; \quad$ SRD $=0$. \\ WSEL SA\# AREA K TOPW WETP ALPH LEW REW QCR

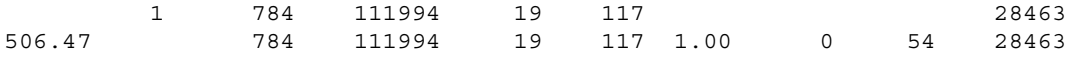 \\ VELOCITY DISTRIBUTION: ISEQ $=3 ;$ SECID $=$ BRIDG; $\operatorname{SRD}=0$.

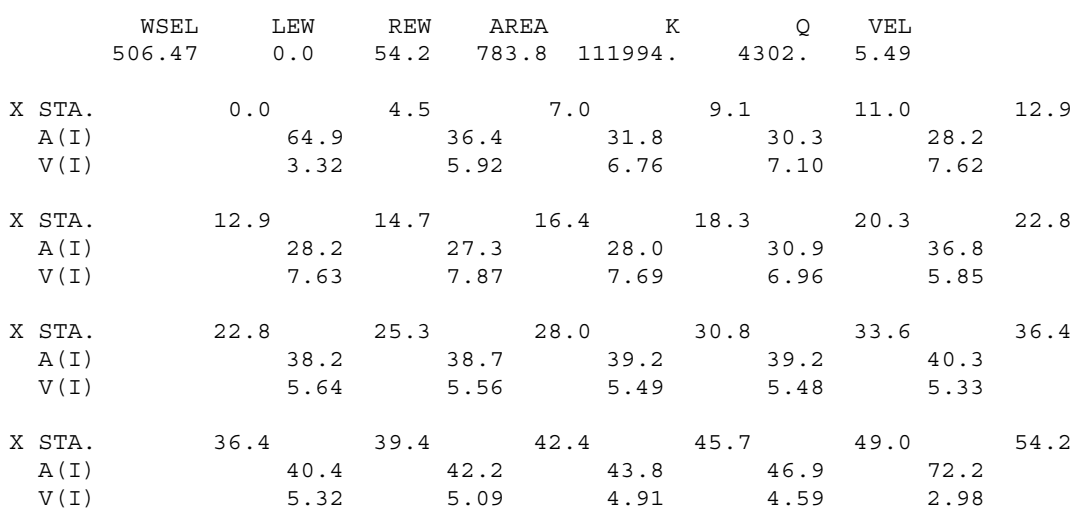 \\ VELOCITY DISTRIBUTION: ISEQ $=4 ; \operatorname{SECID}=$ RDWAY $; \quad \operatorname{SRD}=15$.

\begin{tabular}{|c|c|c|c|c|c|c|c|c|c|c|c|}
\hline & & SEL & LEW & REW & ARE & $E A$ & $\mathrm{~K}$ & Q & VEL & & \\
\hline & 506 & .77 & 9.8 & 669.5 & 878. & .6 & 763. & 5498 . & 6.26 & & \\
\hline $\mathrm{x}$ & STA. & 119.8 & & 190.6 & & 210.8 & 226 & 6.9 & 241.3 & & 254.9 \\
\hline & $A(I)$ & & 65.3 & & 42.6 & & 8.9 & 36.2 & & 35.4 & \\
\hline & $V(I)$ & & 4.21 & & 6.45 & & .06 & 7.59 & & 7.77 & \\
\hline $\mathrm{x}$ & STA. & 254. & & 267.5 & & 279.6 & 291 & 1.5 & 303.8 & & 316.8 \\
\hline & $A(I)$ & & 34.0 & & 33.8 & & 3.4 & 33.7 & & 35.2 & \\
\hline & $\mathrm{V}(\mathrm{I})$ & & 8.10 & & 8.13 & & .22 & 8.15 & & 7.81 & \\
\hline $\mathrm{x}$ & STA. & 316.8 & & 330.0 & & 344.0 & 359 & 9.3 & 375.3 & & 393.2 \\
\hline & $A(I)$ & & 34.9 & & 36.3 & & 8.4 & 38.6 & & 41.3 & \\
\hline & $V(I)$ & & 7.88 & & 7.57 & & .16 & 7.12 & & 6.66 & \\
\hline $\mathrm{X}$ & STA. & 393.2 & & 413.6 & & 437.7 & 468 & 3.6 & 511.1 & & 669.5 \\
\hline & $A(I)$ & & 44.3 & & 47.8 & & 3.9 & 61.1 & & 93.4 & \\
\hline & $V(I)$ & & 6.20 & & 5.75 & & .10 & 4.50 & & 2.94 & \\
\hline & CROSS - & SECTION & PROPER & RTIES: & ISEQ & 5 ; & SECID & $=\mathrm{APPRO} ;$ & SRD & $=$ & 80. \\
\hline & WSEL & SA\# & AREA & & K & TOPW & WETP & ALPH & LEW & REW & QCR \\
\hline & & 1 & 266 & & 506 & 44 & 46 & & & & 3693 \\
\hline & & 2 & 1156 & 178 & 3182 & 78 & 81 & & & & 25300 \\
\hline & & 3 & 3076 & 2356 & 666 & 819 & 819 & & & & 33836 \\
\hline & 507.26 & & 4498 & 4443 & 354 & 941 & 945 & 1.39 & -54 & 886 & 47375 \\
\hline
\end{tabular} \\ VELOCITY DISTRIBUTION: ISEQ $=5 ;$ SECID $=$ APPRO; $\quad$ SRD $=\quad 80$.

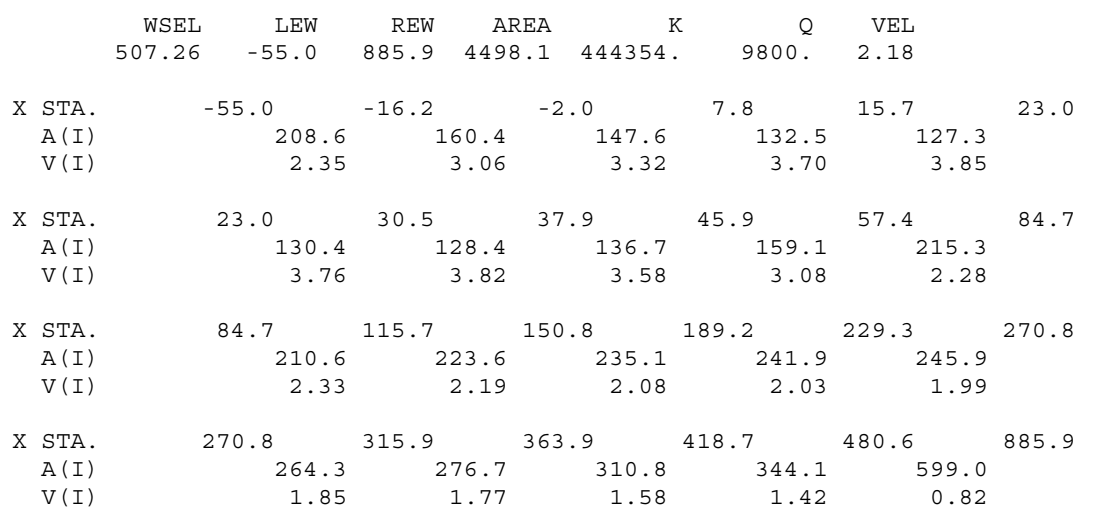


WSPRO OUTPUT FILE (continued)

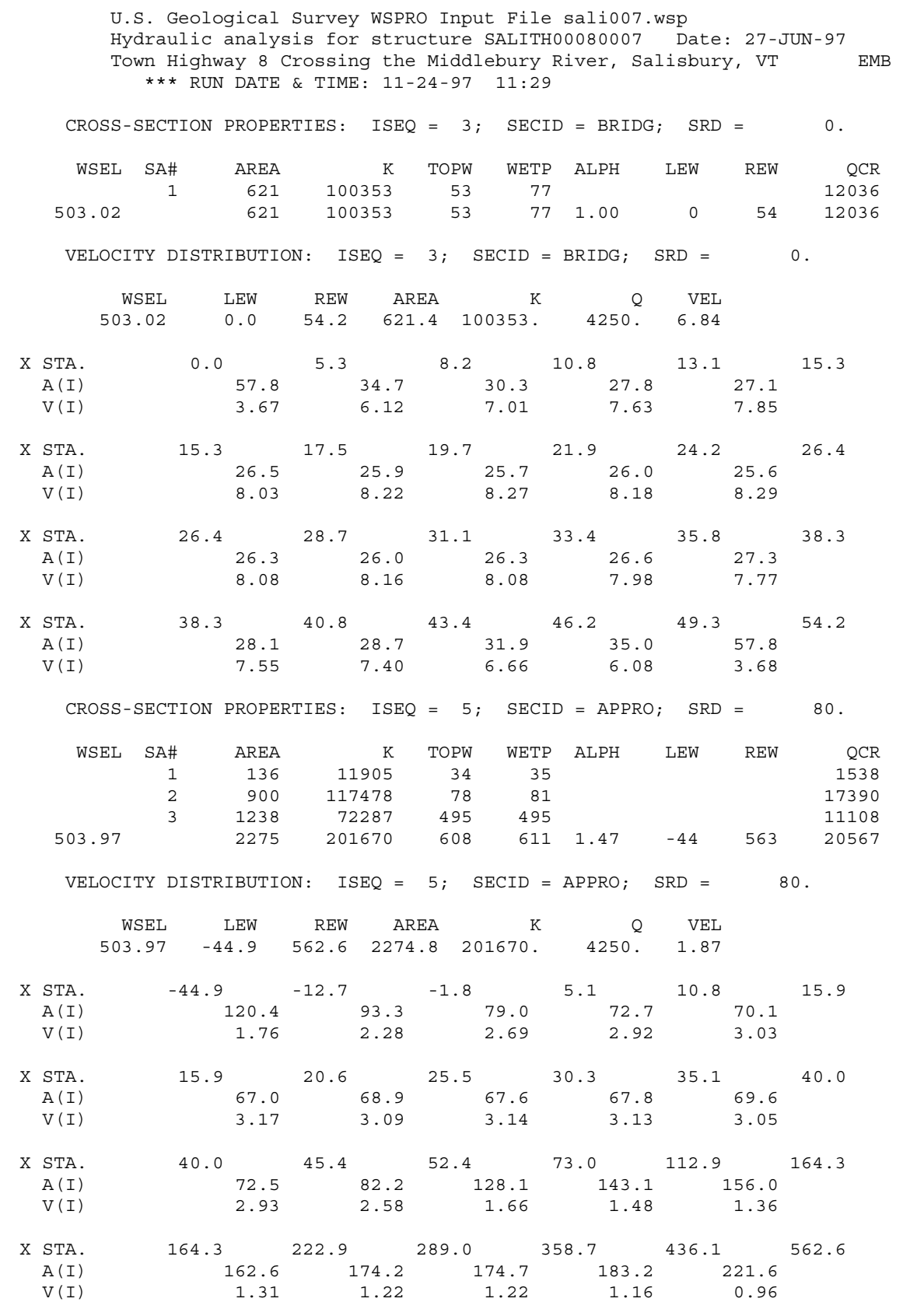


WSPRO OUTPUT FILE (continued)

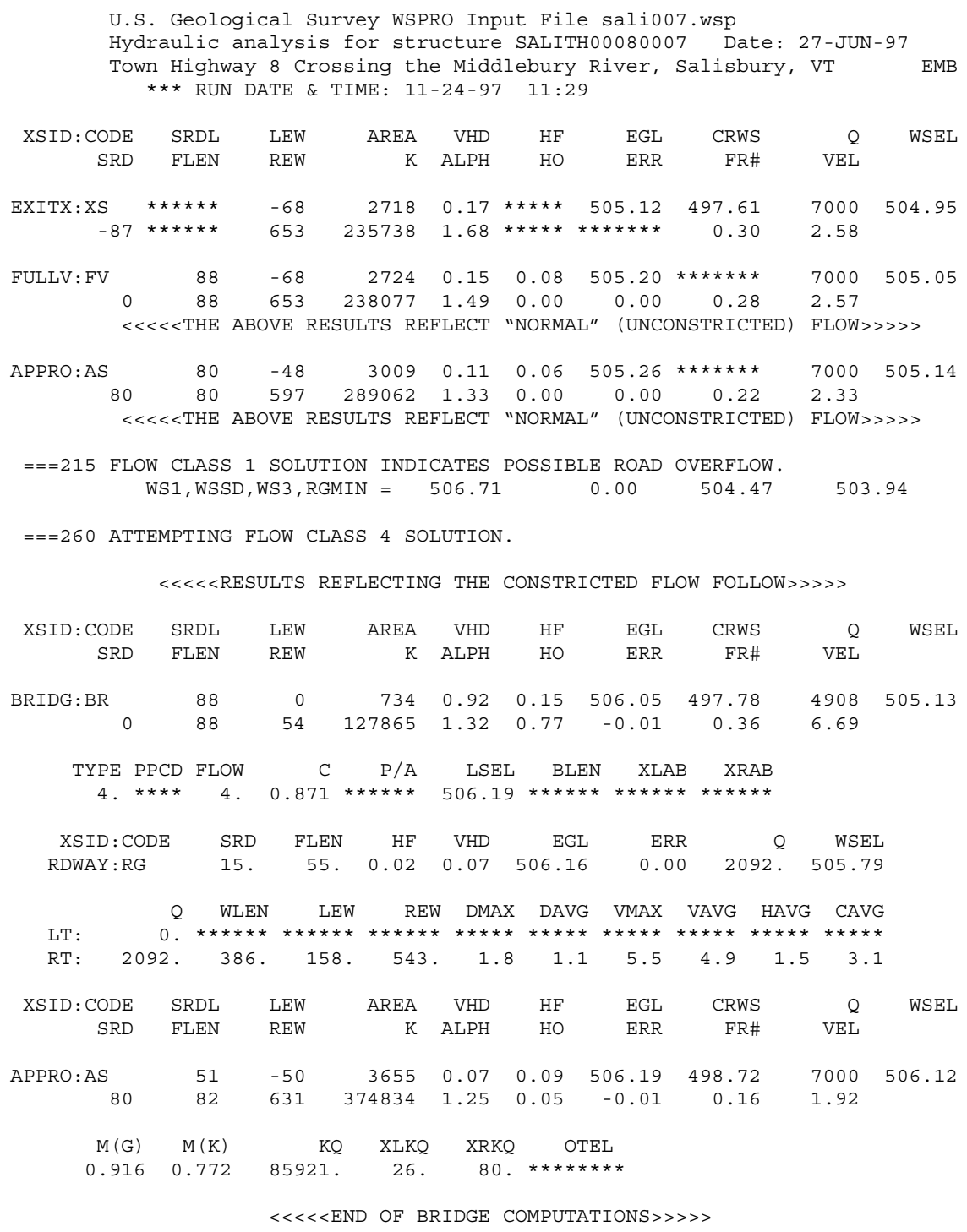

FIRST USER DEFINED TABLE.

\begin{tabular}{|c|c|c|c|c|c|c|c|c|}
\hline XSID : CODE & SRD & LEW & REW & Q & $\mathrm{K}$ & AREA & VEL & WSEL \\
\hline EXITX:XS & -88. & -69. & 653. & 7000. & 235738 . & 2718. & 2.58 & 504.95 \\
\hline FULLV : FV & 0 . & -69. & 653. & 7000 . & 238077 . & 2724 . & 2.57 & 505.05 \\
\hline BRIDG : BR & 0 . & 0 . & 54 & 4908. & 127865 . & 734 & 6.69 & 505.13 \\
\hline RDWAY : RG & 15. & $* \star \star * \star$ & 0 & 2092 . & \multicolumn{2}{|c|}{$0 . * * * * * * * * *$} & 2.00 & 505.79 \\
\hline APPRO : AS & 80. & -51 & 631. & 7000. & 374834 . & 3655. & 1.92 & 506.12 \\
\hline XSID : CODE & XLKQ & XRKQ & & & & & & \\
\hline APPRO : AS & 26. & 80. & 85921 & & & & & \\
\hline
\end{tabular}

SECOND USER DEFINED TABLE.

$\begin{array}{ccrrrrrrrr}\text { XSID : CODE } & \text { CRWS } & \text { FR\# } & \text { YMIN } & \text { YMAX } & \text { HF } & \text { HO } & \text { VHD } & \text { EGL } & \text { WSEL } \\ \text { EXITX:XS } & 497.61 & 0.30 & 488.88 & 525.66 * * * * * * * * * * & 0.17 & 505.12 & 504.95 \\ \text { FULLV:FV } & * * * * * * * * & 0.28 & 490.58 & 525.66 & 0.08 & 0.00 & 0.15 & 505.20 & 505.05 \\ \text { BRIDG : BR } & 497.78 & 0.36 & 490.58 & 507.18 & 0.15 & 0.77 & 0.92 & 506.05 & 505.13 \\ \text { RDWAY:RG } & * * * * * * * * * * * * * * * & 503.94 & 528.12 & 0.02 * * * * * * & 0.07 & 506.16 & 505.79 \\ \text { APPRO:AS } & 498.72 & 0.16 & 489.64 & 512.33 & 0.09 & 0.05 & 0.07 & 506.19 & 506.12\end{array}$


WSPRO OUTPUT FILE (continued)

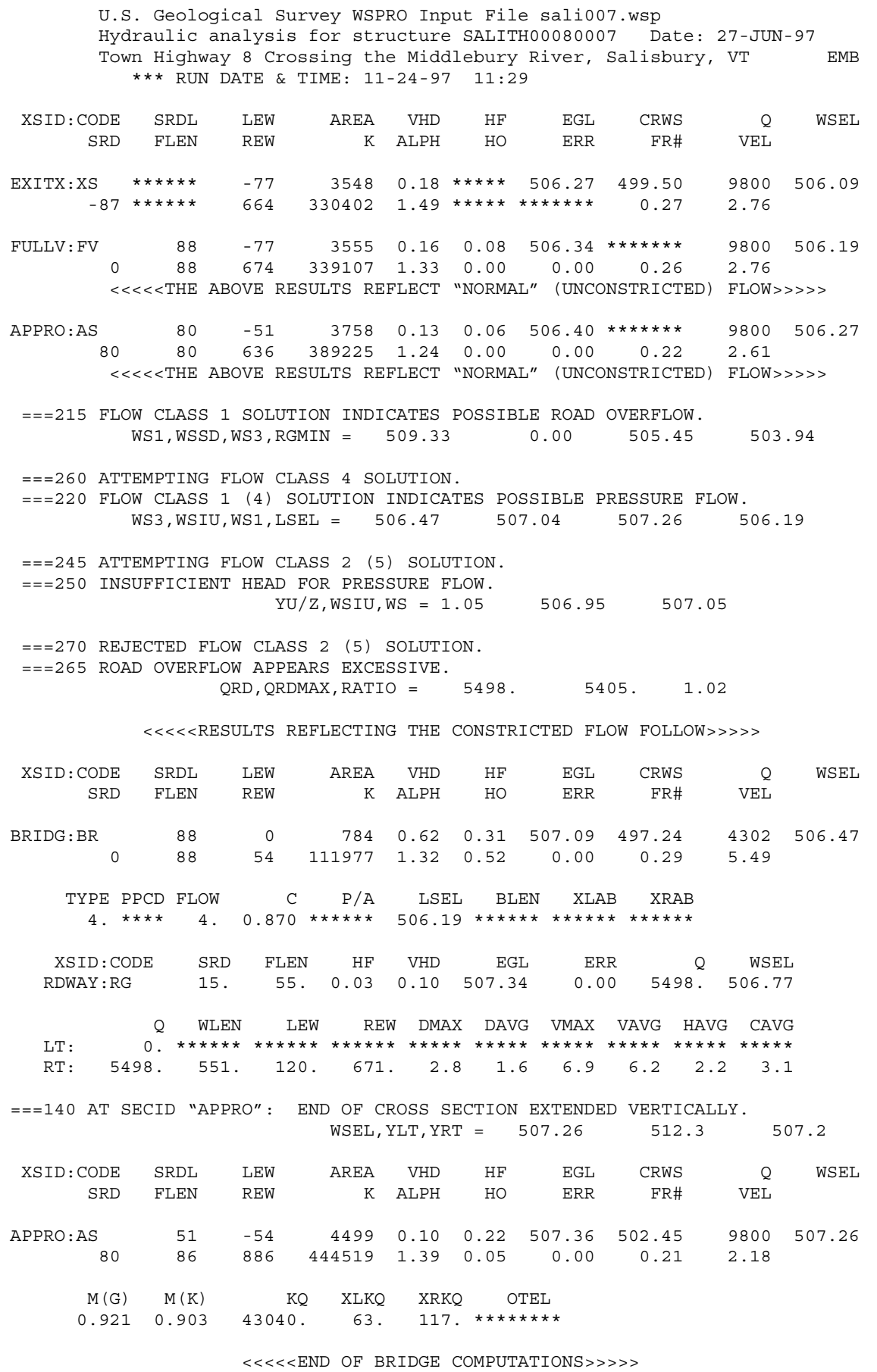

FIRST USER DEFINED TABLE.

\begin{tabular}{|c|c|c|c|c|c|c|c|c|}
\hline XSID: CODE & $\mathrm{SRD}$ & LEW & REW & 0 & $\mathrm{~K}$ & AREA & VEL & WSEL \\
\hline EXITX:XS & -88 . & -78 & 664. & 9800. & 330402 . & 3548 . & 2.76 & 506.09 \\
\hline FULLV : FV & 0 . & -78. & 674. & 9800. & 339107. & 3555 . & 2.76 & 506.19 \\
\hline BRIDG : BR & 0 . & 0 . & 54. & 4302 . & 111977. & 784. & 5.49 & 506.47 \\
\hline RDWAY : RG & 15. & $* \star \star \star \star *$ & 0 . & 5498. & 0 & 0 & 2.00 & 506.77 \\
\hline APPRO : AS & 80. & -55. & 886. & 9800. & 444519 . & 4499. & 2.18 & 507.26 \\
\hline XSID : CODE & XLKQ & $\mathrm{XRKQ}$ & & & & & & \\
\hline APPRO : AS & 63. & 117. & 43040 & & & & & \\
\hline
\end{tabular}

SECOND USER DEFINED TABLE.

\begin{tabular}{|c|c|c|c|c|c|c|c|c|c|}
\hline :CODI & CRWS & FR\# & YMIN & YMAX & $\mathrm{HF}$ & HO & VHD & EGL & \\
\hline XXITX & & .27 & 88.88 & $25.66 * *$ & 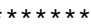 & $\star \star \star$ & 0.18 & 06.27 & \\
\hline UI & 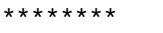 & 26 & 58 & 66 & 0.08 & 0.00 & & & \\
\hline $\mathrm{R}$ & & 0.29 & 58 & & & 0.52 & 62 & & \\
\hline & 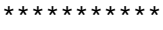 & $\star * \star * *$ & 503.94 & 28.12 & $0.03 * *$ & 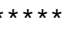 & 0.10 & 07.34 & 00 \\
\hline PPRO : AS & 502.45 & 0.21 & 489.64 & 512.33 & 0.22 & 0.05 & 0.10 & 507.36 & 507. \\
\hline
\end{tabular}


WSPRO OUTPUT FILE (continued)

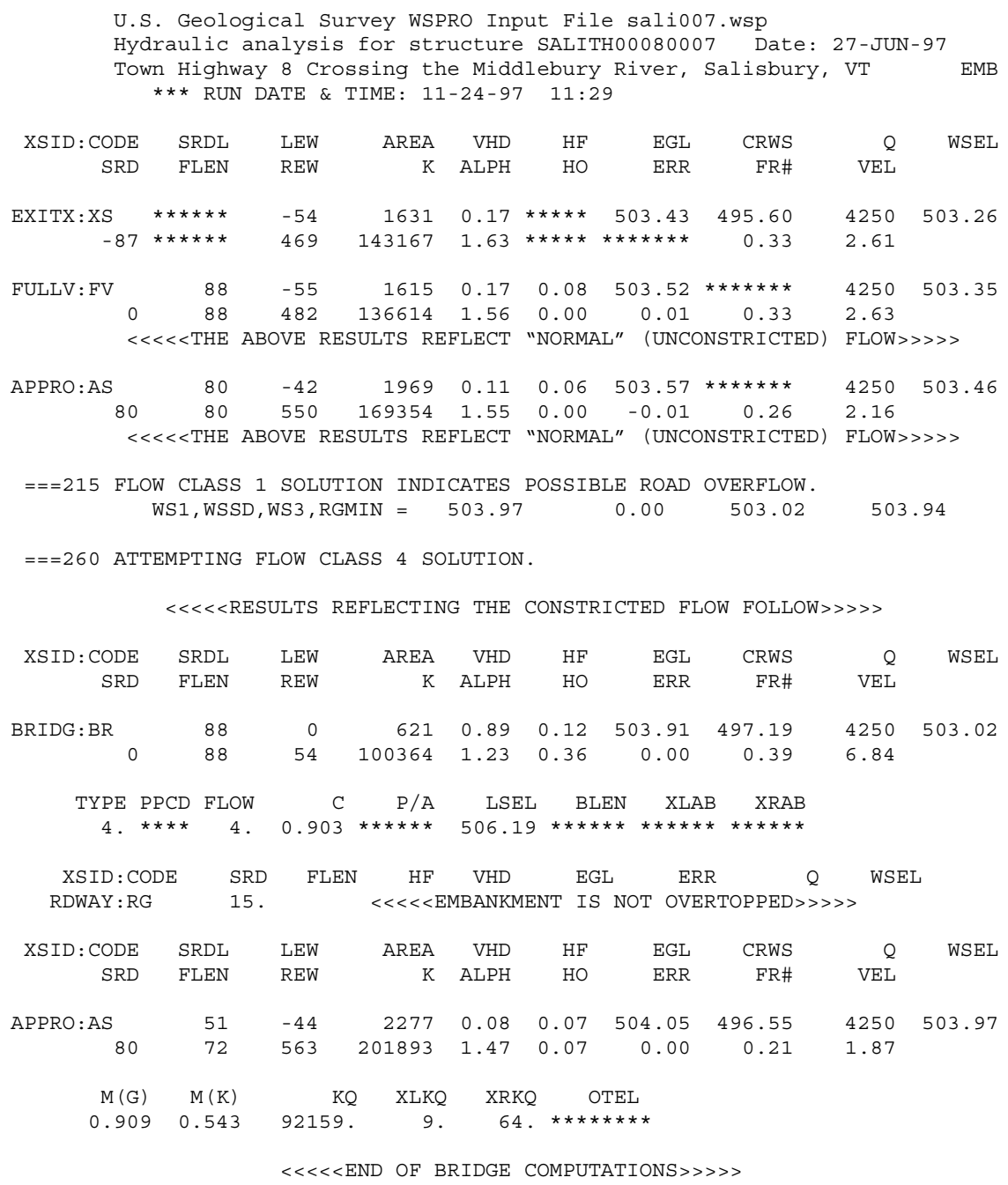

FIRST USER DEFINED TABLE.

\begin{tabular}{|c|c|c|c|c|c|c|c|c|}
\hline XSID : CODE & SRD & LEW & REW & 0 & $\mathrm{~K}$ & AREA & VEL & WSEL \\
\hline EXITX:XS & -88 & -55. & 469. & 4250. & 143167. & 1631. & 2.61 & 503.26 \\
\hline FULLV : FV & 0 . & -56. & 482 . & 4250 . & 136614 . & 1615. & 2.63 & 503.35 \\
\hline BRIDG : BR & 0 . & 0 . & 54. & 4250. & 100364. & 621 & 6.84 & 503.02 \\
\hline RDWAY : RG & \multicolumn{3}{|c|}{ 15. $* * * * * * * * * * * * * *$} & 0 & 0 . & 0 . & \multicolumn{2}{|c|}{$2.00 * * * * * * * *$} \\
\hline APPRO : AS & 80. & -45 & 563. & 4250 . & 201893. & 2277 . & 1.87 & 503.97 \\
\hline XSID : CODE & XLKQ & XRKQ & & & & & & \\
\hline APPRO : AS & 9. & 64. & 9215 & & & & & \\
\hline
\end{tabular}

SECOND USER DEFINED TABLE.

$\begin{array}{lcccccccrr}\text { XSID:CODE } & \text { CRWS } & \text { FR\# } & \text { YMIN } & \text { YMAX } & \text { HF } & \text { HO } & \text { VHD } & \text { EGL } & \text { WSEL } \\ \text { EXITX:XS } & 495.60 & 0.33 & 488.88 & 525.66 * * * * * * * * * * & 0.17 & 503.43 & 503.26 \\ \text { FULLV:FV } & * * * * * * * & 0.33 & 490.58 & 525.66 & 0.08 & 0.00 & 0.17 & 503.52 & 503.35 \\ \text { BRIDG:BR } & 497.19 & 0.39 & 490.58 & 507.18 & 0.12 & 0.36 & 0.89 & 503.91 & 503.02 \\ \text { RDWAY:RG } & * * * * * * * * * * * * * * * & 503.94 & 528.12 & 0.02 * * * * * * & 0.08 & 504.03 * * * * * * * \\ \text { APPRO:AS } & 496.55 & 0.21 & 489.64 & 512.33 & 0.07 & 0.07 & 0.08 & 504.05 & 503.97 \\ \text { ER } & & & & & & & & & \end{array}$




\section{APPENDIX C:}

\section{BED-MATERIAL PARTICLE-SIZE DISTRIBUTION}




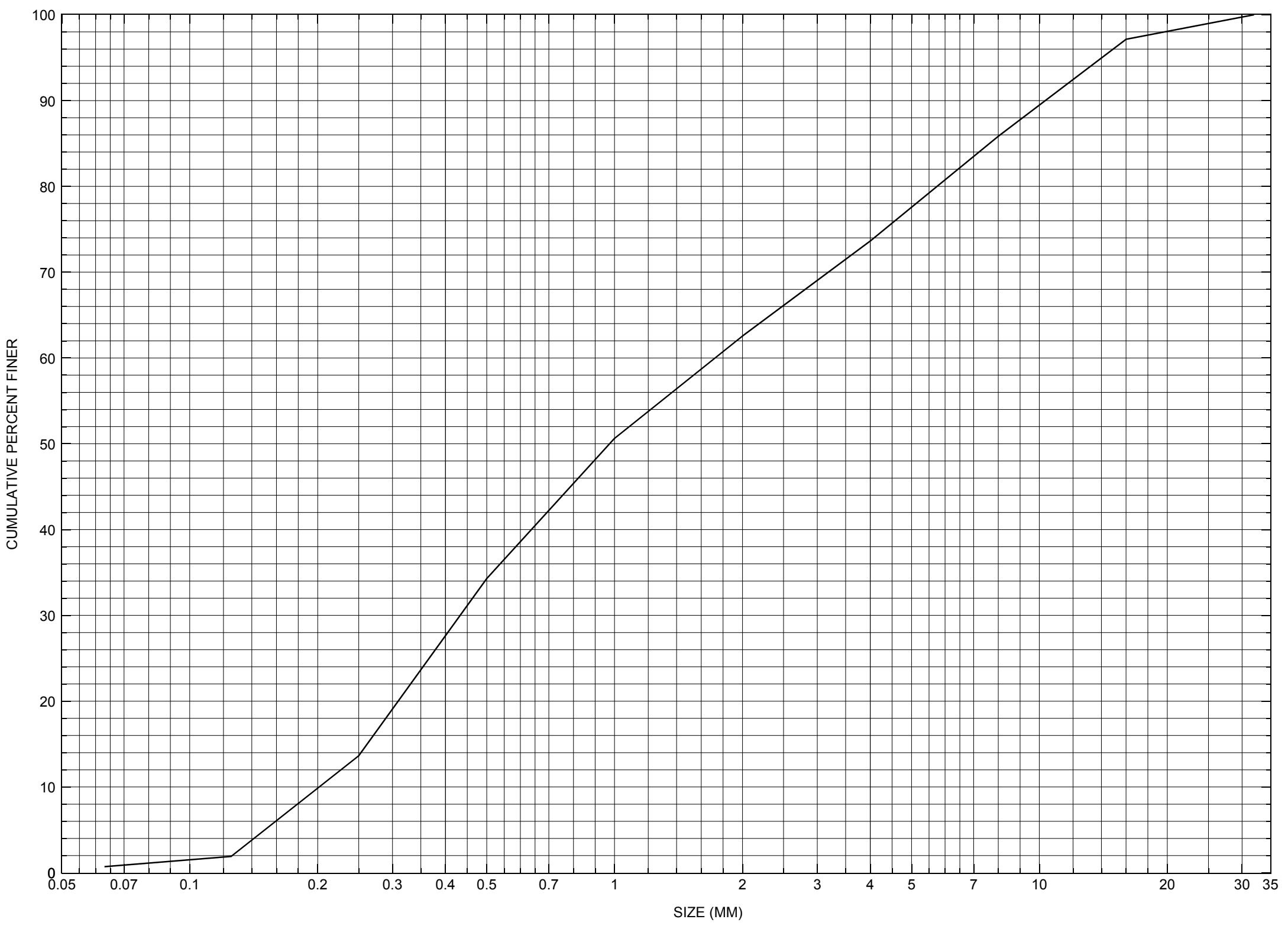

Appendix C. Bed material particle-size distribution for a sediment sample from the channel approach of structure SALITH00080007, in Salisbury, Vermont. 


\section{APPENDIX D: \\ HISTORICAL DATA FORM}




\section{Structure Number SALITH00080007}

\section{General Location Descriptive}

Data collected by (First Initial, Full last name) $\underline{\mathbf{L}}$. Medalie

Date $(M M / D D / Y Y)+12 / 15 / \underline{95}$

Highway District Number (I - 2; nn) $\mathbf{0 5}$

Town (FIPS place code; I - 4; nnnnn) $\mathbf{6 2 5 7 5}$

Waterway (I - 6) MIDDLEBURY RIVER

Route Number TH 8

Topographic Map Cornwall

Latitude (I - 16; nnnn.n) $\mathbf{4 3 5 7 2}$
County (FIPS county code; I - 3; nnn)

Mile marker (I - 11; nnn.nnn) $\mathbf{0 0 0 0 0 0}$

Road Name (I - 7): -

Vicinity (I - 9) 0.85 MI TO JCT W CL3 TH7

Hydrologic Unit Code: $\mathbf{0 2 0 1 0 0 0 2}$

Longitude (i - 17; nnnnn.n) $\mathbf{7 3 0 7 9}$

\section{Select Federal Inventory Codes}

FHWA Structure Number $(I$ - 8) 10011700070117

Maintenance responsibility $(I-21 ; n n) \quad \mathbf{0 3}$

Year built (I - 27; YYYY) 1972

Average daily traffic, ADT (I - 29; nnnnnn) $\underline{000100}$

Year of ADT (I - 30; YY) $\mathbf{9 2}$

Opening skew to Roadway $(I-34 ; n n) \quad 10$

Operational status $(I-41 ; X) \quad \mathbf{A}$

Structure type (I - 43; nnn) $\mathbf{3 0 2}$

Approach span structure type $(I-44 ; n n n) \quad \mathbf{0 0 0}$

Number of spans (I - 45; nnn) $\mathbf{0 0 1}$

Number of approach spans (I - 46; nnnn) $\mathbf{0 0 0 0}$

Comments:

According to the structural inspection report dated 12/8/94, this structure is a single span steel-beam bridge. The abutment walls, wingwalls, backwalls, and footings are concrete. The concrete has alligator cracks with some leaks overall. Some stone fill is evident around the ends of the wingwalls and a few boulders are evident in front of each abutment. The report indicates the channel has scoured down 1 to 2 feet at the right abutment and 2 to 3 feet at the left abutment. The channel makes a bend of nearly 90 degrees immediately upstream of the bridge. The left abutment footing is exposed. 


\section{Bridge Hydrologic Data}

Is there hydrologic data available? $\mathbf{Y}$ if No, type ctrl-n $h \quad$ VTAOT Drainage area $\left(\mathrm{mi}^{2}\right)$ : 62.5

Terrain character: Flat to mountainous

Stream character \& type:

Streambed material: Silty-sand with some gravel

Discharge Data (cfs):

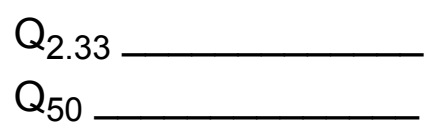
$Q_{10}$ $\mathrm{Q}_{100}$ $\mathrm{Q}_{25}$ $Q_{500}$

Record flood date ( $M M / D D / Y Y$ ): I_ I Water surface elevation (ft):

Estimated Discharge (cfs): Velocity at $\mathrm{Q}$ (ft/s):

Ice conditions (Heavy, Moderate, Light): Moderate Debris (Heavy, Moderate, Light): Moderate The stage increases to maximum highwater elevation (Rapidly, Not rapidly): Not rapidly The stream response is (Flashy, Not flashy):

Describe any significant site conditions upstream or downstream that may influence the stream's stage: $\mathbf{N} / \mathbf{A}$

Watershed storage area (in percent):

The watershed storage area is: - (1-mainly at the headwaters; 2- uniformly distributed; 3-immediatly upstream oi the site)

Water Surface Elevation Estimates for Existing Structure:

\begin{tabular}{|l|l|l|l|l|l|}
\hline Peak discharge frequency & $Q_{2.33}$ & $Q_{10}$ & $Q_{25}$ & $Q_{50}$ & $Q_{100}$ \\
Water surface elevation (ft) & - & - & - & - & - \\
Velocity (ft/sec) & - & - & - & - & - \\
\hline
\end{tabular}

Long term stream bed changes: -

Is the roadway overtopped below the $\mathrm{Q}_{100}$ ? (Yes, No, Unknown): $\mathbf{U}$ Frequency: Relief Elevation $(f t)$ : Discharge over roadway at $Q_{100}\left(f t^{3} / \mathrm{sec}\right)$ :

Are there other structures nearby? (Yes, No, Unknown): $\mathbf{N}$ Upstream distance (miles): Town: If No or Unknown, type ctrl-n os Highway No. : Structure No. : Year Built:

Clear span (ft): Clear Height (ft): Full Waterway $\left(f^{2}\right)$ : 
Downstream distance (miles): Town: Year Built:

Highway No. : Structure No. : Structure Type:

Clear span $(f t):$ Clear Height $(f t)$ : Full Waterway $\left(f^{2}\right)$ :

Comments:

According to a hydraulic data assessment, the stream velocity at the design stage is 9 feet per second (fps). The Q25 is the design discharge of 6000 cfs. The ordinary high water elevation is 486.9 feet while the design high water elevation is $\mathbf{4 9 1 . 4}$ feet. There is a vertical clearance of 1.2 feet at the design stage to the low bridge seat. A check discharge equal to 1.2 times the design discharge (7000 $\mathrm{cfs})$ resulted in a water surface elevation of $\mathbf{4 9 2 . 5}$ feet. The allowable water surface elevation is $\mathbf{4 9 2 . 7}$ feet, which is limited by the low bridge seat.

\section{USGS Watershed Data}

Watershed Hydrographic Data

Drainage area $(D A) \underline{62.43} \mathrm{mi}^{2}$

Watershed storage (ST) $\quad \mathbf{0 . 6 3} \%$

Bridge site elevation $\underline{\mathbf{3 6 0}} \mathrm{ft}$ 西

Main channel length $\mathbf{1 4 . 4 3} \mathrm{mi}$

$10 \%$ channel length elevation $\mathbf{3 6 0}$ $\mathrm{ft} \quad 85 \%$ channel length elevation

1700 $\mathrm{ft}$

Main channel slope (S) $\mathbf{1 2 3 . 8 1} \mathrm{ft} / \mathrm{mi}$

Watershed Precipitation Data

Average site precipitation in Average headwater precipitation in

Maximum 2yr-24hr precipitation event $(124,2) \underline{2.39}$ in

Average seasonal snowfall $(S n) \quad 6.25 \quad \mathrm{ft}$ 


\section{Bridge Plan Data}

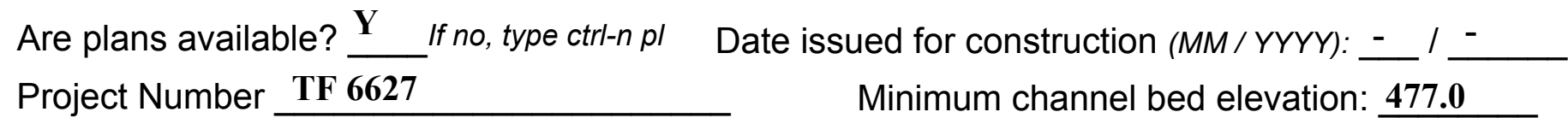

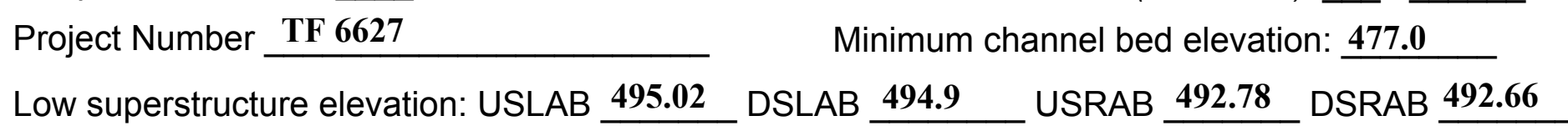

Benchmark location description:

BM \#2 is a spike in the root of a 36" diameter elm tree with an assumed elevation of 500 feet. The tree is located approximately 80 feet in a downstream direction from the bridge and approximately 100 feet up the left bank from the Middlebury River.

Reference Point (MSL, Arbitrary, Other): Arbitrary Datum (NAD27, NAD83, Other): -

Foundation Type: 1

If 1 : Footing Thickness $\mathbf{2}-\mathbf{3}^{*} \quad$ Footing bottom elevation: $\underline{\mathbf{4 7 3 . 0}}$

If 2: Pile Type: __ (1-Wood; 2-Steel or metal; 3-Concrete) Approximate pile driven length:

If 3: Footing bottom elevation:

Is boring information available? $\mathbf{N}$ If no, type ctrl- $n$ bi Number of borings taken: _-

Foundation Material Type: $\mathbf{3}$ (1-regolith, 2-bedrock, 3-unknown)

Briefly describe material at foundation bottom elevation or around piles:

NO FOUNDATION MATERIAL INFORMATION IS AVAILABLE.

\section{Comments:}

* The footing of the left abutment is $\mathbf{2}$ feet thick while that of the right abutment is $\mathbf{3}$ feet thick.

The low superstructure elevations shown above are the bridge seat elevations from the plans. Footing bottom elevations on both the right and left sides are 473.0 feet. The wingwall-abutment top corner elevation is 495.58 feet on the US left, 498.44 feet on the DS left, 496.34 feet on the US right, and 496.2 feet on the DS right. 


\section{Cross-sectional Data}

Is cross-sectional data available? $\underline{\mathbf{Y}}$

If no, type ctrl-n xs

Source (FEMA, VTAOT, Other)? VTAOT

Comments: This cross section is the downstream face. The low chord elevation is from the surveyed data completed for this site on 6/17/96. The low chord to bed length data is from the sketch attached to a bridge inspection report dated 12/8/94. The sketch was done on 11/25/92.

\begin{tabular}{|l|l|l|l|l|l|l|l|l|l|l|l|}
\hline Station & $\mathbf{0}$ & $\mathbf{3 . 1}$ & $\mathbf{1 9 . 8}$ & $\mathbf{3 3 . 4}$ & $\mathbf{4 9 . 2}$ & $\mathbf{5 2 . 5}$ & $\mathbf{5 5 . 6}$ & - & - & - & - \\
\hline Feature & RAB & - & - & - & - & - & LAB & - & - & - & - \\
\hline $\begin{array}{l}\text { Low chord } \\
\text { elevation }\end{array}$ & $\mathbf{5 0 5 . 2}$ & - & - & - & - & - & $\mathbf{5 0 7 . 2}$ & - & - & - & - \\
\hline $\begin{array}{l}\text { Bed } \\
\text { elevation }\end{array}$ & $\mathbf{4 9 1 . 7}$ & - & - & - & - & - & $\mathbf{4 9 2 . 6}$ & - & - & - & - \\
\hline $\begin{array}{l}\text { Low chord } \\
\text { bed length }\end{array}$ & $\mathbf{1 3 . 5}$ & $\mathbf{1 3 . 5}$ & $\mathbf{1 4 . 0}$ & $\mathbf{1 5 . 5}$ & $\mathbf{1 5 . 5}$ & $\mathbf{1 4 . 6}$ & $\mathbf{1 4 . 6}$ & - & - & - & - \\
\hline Station & - & - & - & - & - & - & - & - & - & - & - \\
\hline Feature & - & - & - & - & - & - & - & - & - & - & - \\
\hline $\begin{array}{l}\text { Low cord } \\
\text { elevation }\end{array}$ & - & - & - & - & - & - & - & - & - & - & - \\
\hline $\begin{array}{l}\text { Bed } \\
\text { elevation }\end{array}$ & - & - & - & - & - & - & - & - & - & - & - \\
\hline $\begin{array}{l}\text { Low chord } \\
\text { bed length }\end{array}$ & - & - & - & - & - & - & - & - & - & - & - \\
\hline
\end{tabular}

Source (FEMA, VTAOT, Other)?

Comments: -

\begin{tabular}{|l|l|l|l|l|l|l|l|l|l|l|l|}
\hline Station & - & - & - & - & - & - & - & - & - & - & - \\
\hline Feature & - & - & - & - & - & - & - & - & - & - & - \\
\hline $\begin{array}{l}\text { Low chord } \\
\text { elevation }\end{array}$ & - & - & - & - & - & - & - & - & - & - & - \\
\hline $\begin{array}{l}\text { Bed } \\
\text { elevation }\end{array}$ & - & - & - & - & - & - & - & - & - & - & - \\
\hline $\begin{array}{l}\text { Low chord } \\
\text { bed length }\end{array}$ & - & - & - & - & - & - & - & - & - & - & - \\
\hline Station & - & - & - & - & - & - & - & - & - & - & - \\
\hline Feature & - & - & - & - & - & - & - & - & - & - & - \\
\hline $\begin{array}{l}\text { Low cord } \\
\text { elevation }\end{array}$ & - & - & - & - & - & - & - & - & - & - & - \\
\hline $\begin{array}{l}\text { Bed } \\
\text { elevation }\end{array}$ & - & - & - & - & - & - & - & - & - & - & - \\
\hline $\begin{array}{l}\text { Low chord } \\
\text { bed length }\end{array}$ & - & - & - & - & - & - & - & - & - & - & - \\
\hline
\end{tabular}




\section{APPENDIX E: \\ LEVEL I DATA FORM}


U. S. Geological Survey

Bridge Field Data Collection and Processing Form

Qa/Qc Check by: MS

Date: $\underline{\mathbf{0 7} / \mathbf{0 2} / \mathbf{9 7}}$

\section{Structure Number}

SALITH00080007

Computerized by: $\mathbf{M S}$ Date: $07 / 03 / 97$

Reviewd by:

EMB Date: 8/29/97

\section{A. General Location Descriptive}

1. Data collected by (First Initial, Full last name) L. MEDALIE

2. Highway District Number $\mathbf{0 5}$

Mile marker $\mathbf{0 0 0 0 0 0}$

County Addison (001)

Town Salisbury (62575)

Waterway (I - 6) Middlebury River

Road Name Blake Roy Road

Route Number TH 8

Hydrologic Unit Code: $\mathbf{0 2 0 1 0 0 0 2}$

3. Descriptive comments:

This structure is located $\mathbf{0 . 8 5}$ mile from the junction of Town Highway 7 with Town Highway 8.

\section{B. Bridge Deck Observations}
4. Surface cover... LBUS 4
RBUS 4
LBDS 6
RBDS 3
Overall 4

(2b us, ds,lb,rb: 1- Urban; 2- Suburban; 3- Row crops; 4- Pasture; 5- Shrub- and brushland; 6- Forest; 7- Wetland)
5. Ambient water surface... US 1
UB 1
DS 1
(1- pool; 2- riffle)

6. Bridge structure type 1 (1- single span; 2- multiple span; 3- single arch; 4- multiple arch; 5-cylindrical culvert; 6- box culvert; or 7- other)
7. Bridge length 60
(feet)
Span length $\mathbf{5 7}$
(feet)
Bridge width 24.9 (feet)

\section{Road approach to bridge:}
8. LB 2 RB 1
( 0 even, 1- lower, 2- higher)
9. LB 2 RB 2
(1- Paved, 2- Not paved)

10. Embankment slope (run / rise in feet / foot):
US left
1.6:1
US right
2.0:1

\begin{tabular}{|c|c|c|c|c|}
\hline & \multicolumn{2}{|c|}{ Protection } & \multirow{2}{*}{ 13.Erosion } & \multirow{2}{*}{ 14.Severity } \\
\hline & 11.Type & 12.Cond. & & \\
\hline LBUS & 0 & - & $\mathbf{0}$ & - \\
\hline RBUS & $\mathbf{0}$ & - & 2 & 1 \\
\hline RBDS & 1 & 1 & $\mathbf{0}$ & - \\
\hline LBDS & $\mathbf{0}$ & - & $\mathbf{0}$ & - \\
\hline
\end{tabular}

Bank protection types: 0- none; 1- < 12 inches;

2- < 36 inches; 3- < 48 inches;

4- < 60 inches; 5- wall / artificial levee

Bank protection conditions: 1- good; 2- slumped;

3- eroded; 4- failed

Erosion: 0 - none; 1- channel erosion; 2-

road wash; 3- both; 4- other

Erosion Severity: 0 - none; 1- slight; 2- moderate; 3- severe

\section{Channel approach to bridge (BF):}

15. Angle of approach: $\mathbf{0}$

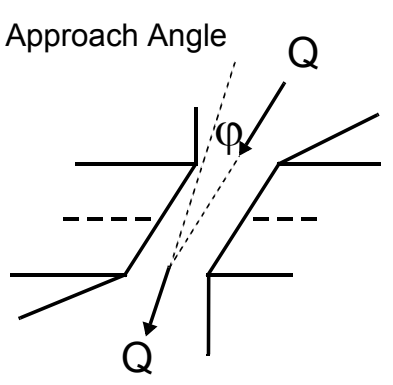

17. Channel impact zone 1 :

Where? LB $(L B, R B)$

Range? 60 feet US

Channel impact zone 2:

Where? _ _ $(L B, R B)$

Range? - $\quad$ feet -

(US, UB, DS) to feet Impact Severity: 0- none to very slight; 1-Slight; 2- Moderate; 3- Severe

16. Bridge skew: 25 Bridge Skew Angle

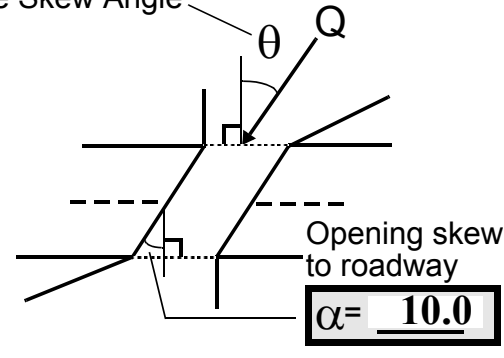

\section{Exist? $\mathbf{Y}(Y$ or $N)$}

Severity 3

(US, UB, DS) to 125 feet $\underline{\mathbf{U S}}$

Exist? $\underline{\mathbf{N}}(\mathrm{Y}$ or $N)$

Severity - 
18. Bridge Type: 4

1a- Vertical abutments with wingwalls

$1 \mathrm{~b}$ - Vertical abutments without wingwalls

2- Vertical abutments and wingwalls, sloping embankment Wingwalls parallel to abut. face

3- Spill through abutments

4- Sloping embankment, vertical wingwalls and abutments

Wingwall angle less than $90^{\circ}$.

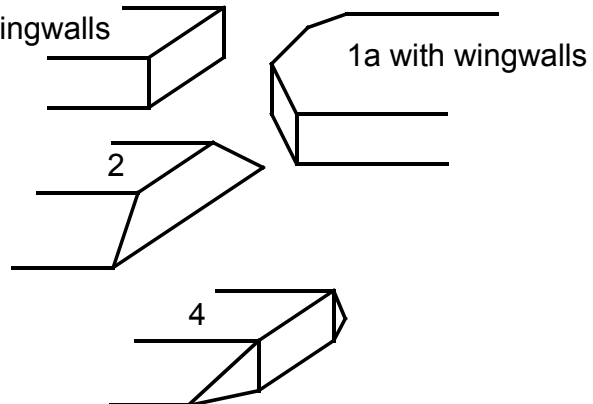

19. Bridge Deck Comments (surface cover variations, measured bridge and span lengths, bridge type variations, approach overflow width, etc.)

The bridge dimensions shown on the previous page are those obtained from the VTAOT database. The measured bridge length, span length, and bridge width were 59 feet, 58 feet, and 24.7 feet respectively. The dense grass coverage helps to stabilize all the road approach embankments. There is road wash located just behind the upstream right wingwall. The DS right bank protection, indicated later in this assessment, is at the end of the DS right wingwall, midway up the slope between the top and bottom of the bank.

\section{Upstream Channel Assessment}

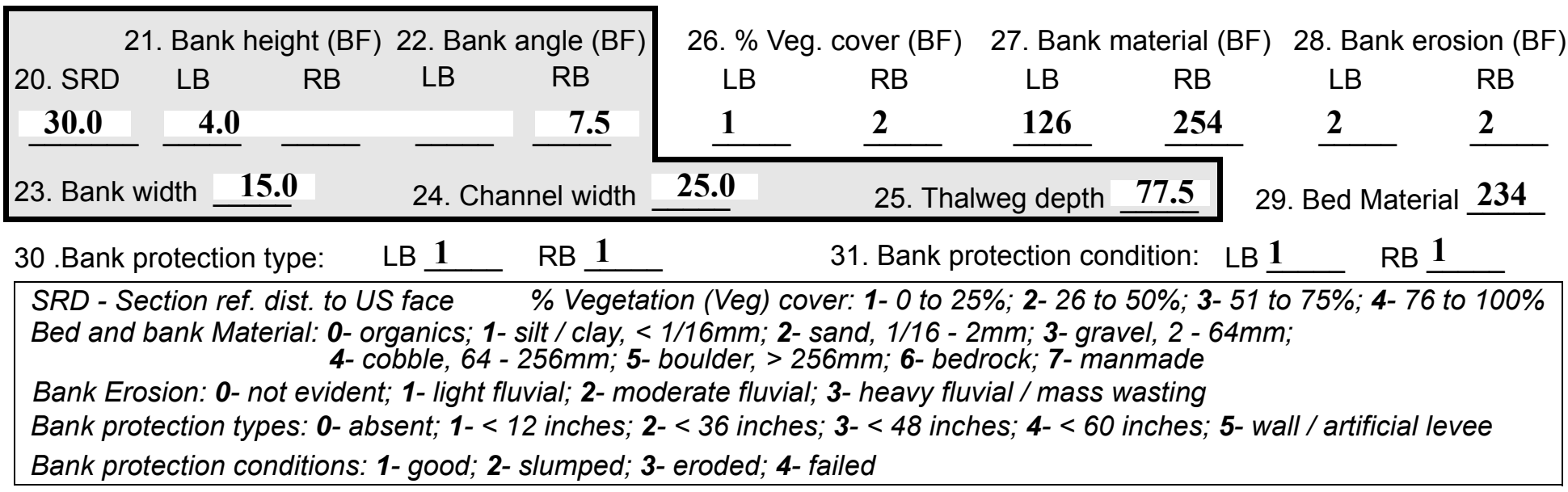

32. Comments (bank material variation, minor inflows, protection extent, etc.):

Both the left bank and the right bank are covered with mostly grass and weeds.

The bed material grades from sand on the right side to cobbles and gravel on the left side of the channel. Bedrock is exposed at the surface along the left bank in the channel from 50 feet to 130 feet upstream.

The right bank protection consists of small pieces of stone where the river bends sharply, about 50 feet upstream of the bridge. The left bank protection extends from under the bridge to 55 feet US. 
37. Material: $\mathbf{2 3}$

38. Point or side bar comments (Circle Point or Side; Note additional bars, material variation, status, etc.):

The point bar is present along the right bank at the sharp bend in the river just upstream. There is a second bar along the right bank located from 5 feet US to 40 feet US. Its mid-bar distance is 30 feet where the width is 8 feet. The bar is composed of sand and it is positioned $93 \% \mathrm{LB}$ to $100 \% \mathrm{RB}$.

39. Is a cut-bank present? $\mathbf{Y}$ (Y or if $N$ type ctrl-n $c b)$

41. Mid-bank distance: 105

43. Bank damage: 3

42. Cut bank extent: $\mathbf{5 0}$
40. Where? $\mathbf{L B}$ (LB or RB) feet $\underline{\mathbf{U S}}$ (US, UB) to $\underline{\mathbf{1 2 0}}$ feet $\underline{\mathbf{U S}}$ (US, UB, DS)

44. Cut bank comments (eg. additional cut banks, protection condition, etc.):

This cut bank area is stabilized by the exposed bedrock.

\section{Is channel scour present? $\mathbf{Y}$ (Y or if $N$ type ctrl-n cs) 46. Mid-scour distance: $\mathbf{8 5}$}
47. Scour dimensions: Length $\mathbf{8 0}$
Width $\mathbf{5 0}$
Depth : 4
Position 10
$\%$ LB to $\underline{\mathbf{5 0}}$
$\%$ RB

48. Scour comments (eg. additional scour areas, local scouring process, etc.):

There is another scour hole on the right bank that is located between the point bars along the right bank. The length is $\mathbf{1 5}$ feet, the width is $\mathbf{5}$ feet, and the depth is 2.5 feet. The average thalweg depth is 3 feet.

\section{Are there major confluences? Y ( $Y$ or if $N$ type ctrl-n $m c)$ \\ 51. Confluence 1: Distance - \\ Confluence 2: Distance - \\ 52. Enters on $\underline{\mathbf{L B}}$ (LB or $R B)$ \\ Enters on - (LB or $R B)$}

54. Confluence comments (eg. confluence name):

The distance upstream to this confluence was not measured. The name of the tributary is Halnon Brook.

\section{Under Bridge Channel Assessment}

55. Channel restraint (BF)? LB 2

\begin{tabular}{|ccccc|}
\hline \multicolumn{2}{|c}{ 56. Height (BF) } & \multicolumn{3}{c}{57 Angle (BF) } \\
LB & RB & LB & RB \\
$\mathbf{5 1 . 5}$ & & & $\mathbf{3 . 0}$ & \\
\hline
\end{tabular}

58. Bank width (BF) -

59. Channel width (1- natural bank; 2- abutment; 3- artificial levee)

Bed and bank Material: 0- organics; 1- silt / clay, < 1/16mm; 2- sand, 1/16 - 2mm; 3- gravel, 2 - 64mm; 4- cobble, 64 - 256mm; 5- boulder, > 256mm; 6- bedrock; 7- manmade

\begin{tabular}{|c|c|c|c|}
\hline \multicolumn{2}{|c|}{ 61. Material (BF) } & \multicolumn{2}{|c|}{ 62. Erosion (BF) } \\
\hline LB & $\mathrm{RB}$ & LB & $\mathrm{RB}$ \\
\hline 2 & 7 & 7 & - \\
\hline
\end{tabular}

60. Thalweg depth $\lcm{90.0}$

63. Bed Material -

Bank Erosion: 0- not evident; 1- light fluvial; 2- moderate fluvial; 3- heavy fluvial / mass wasting

64. Comments (bank material variation, minor inflows, protection extent, etc.):

234

The bed material grades from fine to coarse material from the right to the left. 
65. Debris and Ice Is there debris accumulation?

(Yor $N)$ 66. Where? $\underline{Y}$ (1- Upstream; 2- At bridge; 3- Both)

67. Debris Potential 1 ( 1- Low; 2- Moderate; 3- High) 68. Capture Efficiency 2 (1-Low; 2- Moderate; 3- High) 69. Is there evidence of ice build-up? 1 (Y or N) Ice Blockage Potential $\underline{\mathbf{Y}}$ (1-Low; 2- Moderate; 3- High)

70. Debris and Ice Comments:

1

The debris accumulation is essentially grass or weed stalks deposited on the island during high water.

The debris potential is low because there are few trees located near the banks.

There are gouges in the bark of several trees along the banks suggesting ice build-up may be significant along the reach.

\begin{tabular}{|l|c|c|c|c|c|c|c|c|}
\hline Abutments & $\begin{array}{c}\text { 71. Attack } \\
\angle \text { (BF) }\end{array}$ & $\begin{array}{c}\text { 72. Slope } \angle \\
\text { (Qmax) }\end{array}$ & $\begin{array}{c}\text { 73. Toe } \\
\text { loc. (BF) }\end{array}$ & $\begin{array}{c}\text { 74. Scour } \\
\text { Condition }\end{array}$ & $\begin{array}{c}\text { 75. Scour } \\
\text { depth }\end{array}$ & $\begin{array}{c}\text { 76. Exposure } \\
\text { depth }\end{array}$ & 77. Material & 78. Length \\
\hline LABUT & & $\mathbf{0}$ & $\mathbf{9 0}$ & $\mathbf{2}$ & $\mathbf{2}$ & - & $\mathbf{2 . 5}$ & $\mathbf{9 0 . 0}$ \\
\hline RABUT & $\mathbf{1}$ & $\mathbf{0}$ & $\mathbf{9 0}$ & & & $\mathbf{2}$ & $\mathbf{1}$ & $\mathbf{5 3 . 5}$ \\
\hline
\end{tabular}

Pushed: $L B$ or RB

Toe Location (Loc.): 0- even, 1- set back, 2- protrudes

Scour cond.: 0- not evident; 1- evident (comment); 2- footing exposed; 3-undermined footing; 4- piling exposed; 5- settled; 6- failed

Materials: 1- Concrete; 2- Stone masonry or drywall; 3- steel or metal; 4- wood

79. Abutment comments (eg. undermined penetration, unusual scour processes, debris, etc.):

-

1

Along the right abutment, the streambed is about one foot below the water surface up to about 2 to 3 feet from the wall. At the upstream wingwall, the depth is 2.5 feet. At the DS end of the right abutment, the top of the footing can be detected with a range pole approximately 3 to 4 inches below the streambed surface.

80. Wingwalls:

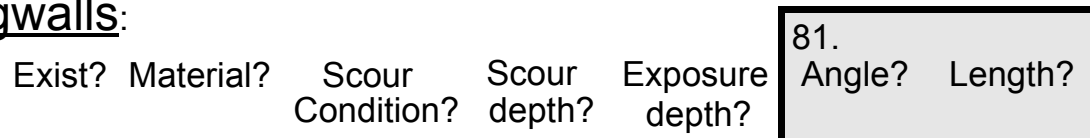

USLWW:
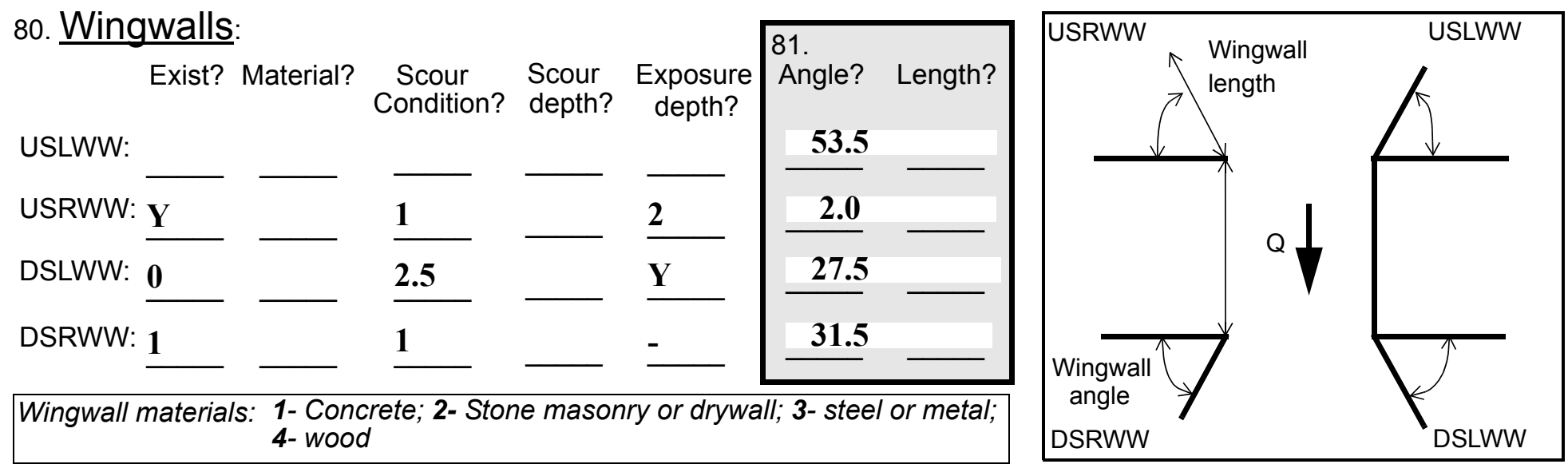

82. Bank / Bridge Protection:

\begin{tabular}{|l|l|l|l|l|l|l|l|l|}
\hline Location & USLWW & USRWW & LABUT & RABUT & LB & RB & DSLWW & DSRWW \\
\hline Type & - & $\mathbf{2}$ & $\mathbf{Y}$ & - & $\mathbf{1}$ & $\mathbf{1}$ & $\mathbf{1}$ & - \\
\hline Condition & $\mathbf{Y}$ & - & $\mathbf{1}$ & - & $\mathbf{1}$ & $\mathbf{2}$ & $\mathbf{2}$ & - \\
\hline Extent & $\mathbf{1}$ & $\mathbf{0 . 5}$ & $\mathbf{0}$ & $\mathbf{2}$ & $\mathbf{1}$ & $\mathbf{2}$ & $\mathbf{0}$ & - \\
\hline
\end{tabular}

Bank / Bridge protection types: 0- absent; 1- < 12 inches; 2- < 36 inches; 3- < 48 inches; 4- < 60 inches; 
83. Wingwall and protection comments (eg. undermined penetration, unusual scour processes, etc.):

-
-
-
-
-
0
-
-
1
1
1

\section{Piers:}

84. Are there piers? Th (Y or if $N$ type ctrl-n pr)

\begin{tabular}{|l|l|l|l|l|l|l||}
\hline \multirow{2}{*}{$\begin{array}{l}85 . \\
\text { Pier no. }\end{array}$} & \multicolumn{3}{|c|}{ width (w) feet } & \multicolumn{3}{c|}{ elevation (e) feet } \\
\cline { 2 - 8 } & w1 & w2 & w3 & e@w1 & e@w2 & e@w3 \\
\hline Pier 1 & & & & $\mathbf{3 0 . 0}$ & $\mathbf{2 4 . 0}$ & $\mathbf{5 5 . 0}$ \\
\hline Pier 2 & & & & $\mathbf{1 6 . 0}$ & $\mathbf{4 5 . 0}$ & $\mathbf{2 1 . 0}$ \\
\hline Pier 3 & & & - & $\mathbf{5 0 . 0}$ & $\mathbf{1 3 . 0}$ & - \\
\hline Pier 4 & - & - & - & - & - & - \\
\hline
\end{tabular}

\begin{tabular}{|l|l|l|l|l|}
\hline Level 1 Pier Descr. & \multicolumn{1}{|c|}{1} & \multicolumn{1}{|c|}{2} & \multicolumn{1}{|c|}{3} & \multicolumn{1}{|c|}{4} \\
\hline 86. Location (BF) & e foot- & but is & first 10 & ment, \\
\hline 87. Type & ing & cov- & feet & the \\
\hline 88. Material & of & ered & of & wing \\
\hline 89. Shape & the & by & the & wall \\
\hline 90. Inclined? & US & $\mathbf{0 . 5}$ & DS & is \\
\hline 91. Attack $\angle$ (BF) & right & to 1 & left & con- \\
\hline 92. Pushed & wing & foot & wing & crete \\
\hline 93. Length (feet) & - & - & - & - \\
\hline 94. \# of piles & wall & of & wall & - \\
\hline 95. Cross-members & is & loose & from & Then \\
\hline 96. Scour Condition & not & sand. & the & the \\
\hline 97. Scour depth & expo & For & left & wing \\
\hline 98. Exposure depth & sed & the & abut & wall \\
\hline
\end{tabular}

LFP, LTB, LB, MCL, MCM, MCR, RB, RTB, RFP

1- Solid pier, 2- column, 3- bent

1-Wood; 2- concrete; 3- metal; 4- stone

1- Round; 2- Square; 3- Pointed

Y-yes; $N$ - no

$L B$ or $R B$

0- none; 1- laterals; 2- diagonals; 3- both

0- not evident; 1- evident (comment);

2- footing exposed; 3- piling exposed;

4- undermined footing; 5- settled; 6- failed 
99. Pier comments (eg. undermined penetration, protection and protection extent, unusual scour processes, etc.):

is a "laid-up" stone wall. The US left wingwall protection is located mostly at the center and the upstream end of the wingwall. However, the protection is very sparse at the corner of the upstream left wingwall and the upstream end of the left abutment.

$\mathbf{N}$

100.

\section{E. Downstream Channel Assessment}

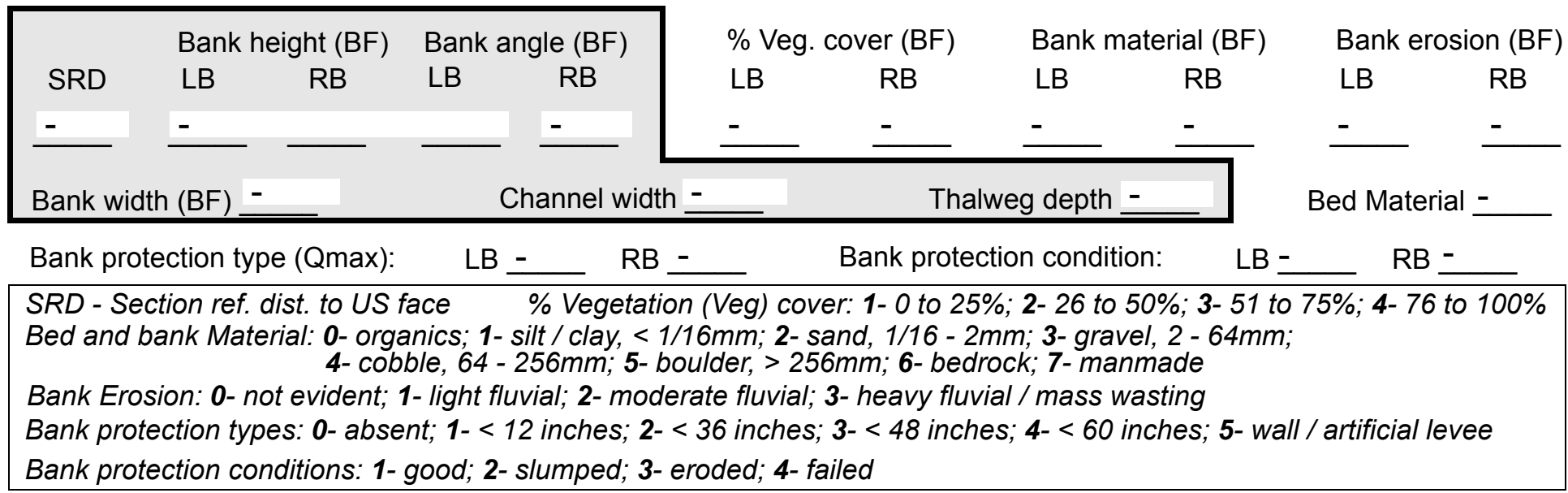

Comments (eg. bank material variation, minor inflows, protection extent, etc.):

$-$

$-$

-

-

-

-

-

-

-

$-$

$-$

\section{Is a drop structure present? _ ( $Y$ or $N$, if $N$ type ctrl-n ds) 102. Distance: _ _ feet}
103. Drop: - feet
104. Structure material:
(1- steel sheet pile; 2- wood pile; 3- concrete; 4- other)

105. Drop structure comments (eg. downstream scour depth):

-

$-$

-

- 
106. Point/Side bar present? (Y or $N$. if $N$ type ctrl-n pb)Mid-bar distance:

Mid-bar width: -

Point bar extent: feet -

(US, UB, DS) to feet (US, UB, DS) positioned $\%$ LB to $\% R B$ Material:

Point or side bar comments (Circle Point or Side; note additional bars, material variation, status, etc.):

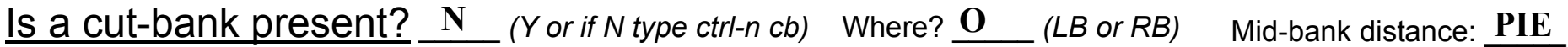
Cut bank extent: RS feet__ (US, UB, DS) to feet (US, UB, DS)

Bank damage: (1- eroded and/or creep; 2- slip failure; 3- block failure)

Cut bank comments (eg. additional cut banks, protection condition, etc.):

Is channel scour present? Scour dimensions: Length $\underline{4}$ Width 16 ( $Y$ or if $N$ type ctrl-n cs) Depth: 145 Mid-scour distance: $\underline{4}$ Scour comments (eg. additional scour areas, local scouring process, etc.): 234

0

2

$-$

Are there major confluences? 1 ( 1 or if $N$ type ctrl-n $m c)$ Confluence 1: Distance bed Enters on mat (LB or RB) Confluence 2: Distance grad Enters on es (LB or $R B)$

Positioned 2 \%LB to 2 $\% \mathrm{RB}$ Confluence comments (eg. confluence name):

$m$ fine sand to bedrock from the right bank to the left bank side of the channel. The bedrock is exposed on the left side of the channel from 10 feet DS to 65 feet DS. The right bank protection extends from 43 feet DS to 67

\section{F. Geomorphic Channel Assessment}

107. Stage of reach evolution fee
1- Constructed

2- Stable

3- Aggraded

4- Degraded

5- Laterally unstable

6- Vertically and laterally unstable 
108. Evolution comments (Channel evolution not considering bridge effects; See HEC-20, Figure 1 for geomorphic descriptors):

$t$ DS, but it is not continuous. Although a considerable amount of material has been eroded, the left bank erosion is moderate because the bedrock prevents instability.

At approximately 100 feet downstream, the percent vegetation cover on both banks reduces to the range of 26 to $50 \%$. 


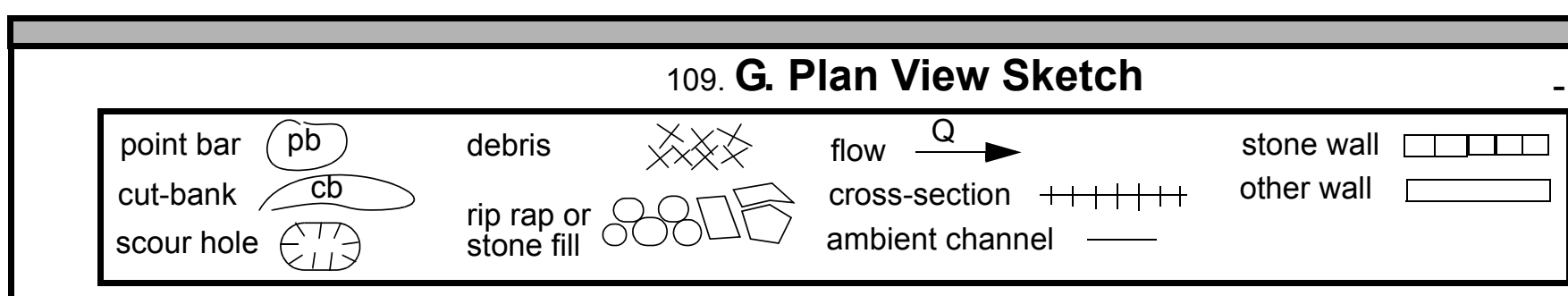


APPENDIX F:

SCOUR COMPUTATIONS 


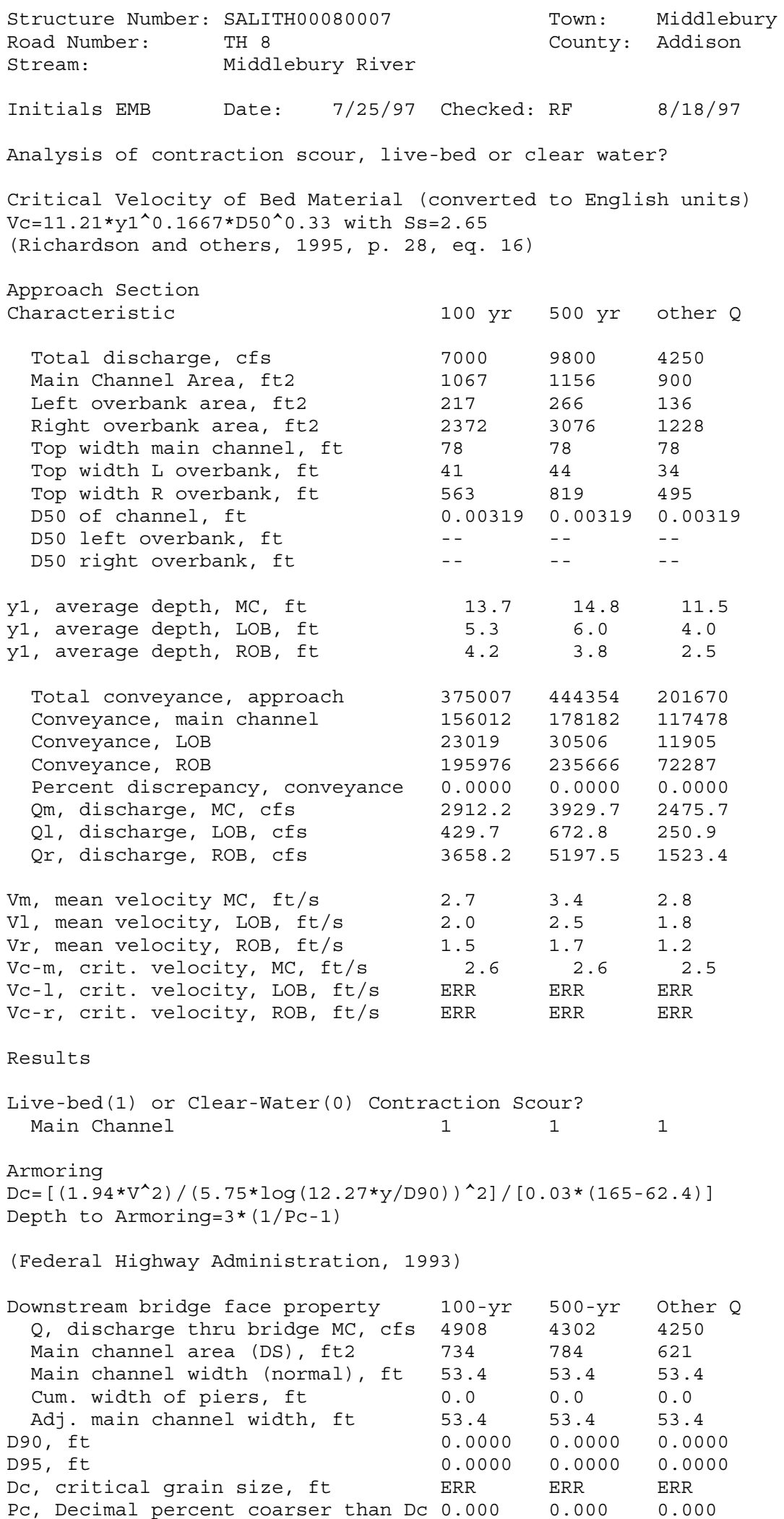




\begin{tabular}{|c|c|c|c|c|c|c|}
\hline \multicolumn{7}{|c|}{$\begin{array}{l}\text { Laursen's Live Bed Contraction Scour } \\
\mathrm{y}^{2 / \mathrm{y} 1}=(\mathrm{Q} 2 / \mathrm{Q} 1)^{\wedge}(6 / 7) *(\mathrm{~W} 1 / \mathrm{W} 2)^{\wedge}(\mathrm{k} 1) \\
\text { ys=y2-y_bridge } \\
\text { (Richardson and others, 1995, p. } 30, \text { eq. } 17 \text { and } 18)\end{array}$} \\
\hline & Approach & & & Bridge & & \\
\hline Characteristic & $100 \mathrm{yr}$ & $500 \mathrm{yr}$ & Other $Q$ & $100 \mathrm{yr}$ & 500 yr & Other $\mathrm{Q}$ \\
\hline Q1, discharge, cfs & 7000 & 9800 & 4250 & 4908 & 4302 & 4250 \\
\hline Total conveyance & 375007 & 444354 & 201670 & 127845 & 111994 & 100353 \\
\hline Main channel conveyance & 156012 & 178182 & 117478 & 127845 & 111994 & 100353 \\
\hline Main channel discharge & 2912 & 3930 & 2476 & 4908 & 4302 & 4250 \\
\hline Area - main channel, ft2 & 1067 & 1156 & 900 & 734 & 784 & 621 \\
\hline (W1) channel width, ft & 78 & 78 & 78 & 53.4 & 53.4 & 53.4 \\
\hline (Wp) cumulative pier width, ft & 0 & 0 & 0 & 0 & 0 & 0 \\
\hline w1, adjusted bottom width(ft) & 78 & 78 & 78 & 53.4 & 53.4 & 53.4 \\
\hline D50, ft & 0.00319 & 0.00319 & 0.00319 & & & \\
\hline w, fall velocity, ft/s (p. 32) & 0.44 & 0.44 & 0.44 & & & \\
\hline $\begin{array}{l}\text { Y, ave. depth flow, ft } \\
\text { sl, slope EGL }\end{array}$ & $\begin{array}{l}13.68 \\
0.00075\end{array}$ & $\begin{array}{l}14.82 \\
0.00075\end{array}$ & $\begin{array}{l}11.54 \\
0.000625\end{array}$ & 13.75 & 14.68 & 11.63 \\
\hline P, wetted perimeter, MC, ft & 81 & 81 & 81 & & & \\
\hline R, hydraulic Radius, ft & 13.173 & 14.272 & 11.111 & & & \\
\hline $\mathrm{V}^{*}$, shear velocity, ft/s & 0.564 & 0.587 & 0.473 & & & \\
\hline $\mathrm{V} * / \mathrm{w}$ & 1.282 & 1.334 & 1.075 & & & \\
\hline $\begin{array}{l}\text { Bed transport coeff., } k 1,(0.59 \text { if } \\
\text { k1 }\end{array}$ & $\begin{array}{l}\mathrm{V} * / \mathrm{W}<0.5 \\
0.64\end{array}$ & $\begin{array}{l}0.64 \text { if } \\
0.64\end{array}$ & $\begin{array}{l}.5<\mathrm{V} * / \mathrm{W}<2 ; \\
0.64\end{array}$ & ; 0.69 if & $\mathrm{V} * / \mathrm{w}>2.0$ & p. 33$)$ \\
\hline $\mathrm{y}^{2}$, depth in contraction, ft & 27.27 & 20.41 & 23.37 & & & \\
\hline ys, scour depth, ft (y2-y_bridge) & 13.52 & 5.73 & 11.74 & & & \\
\hline
\end{tabular}

Clear water Contraction Scour in MAIN CHANNEL

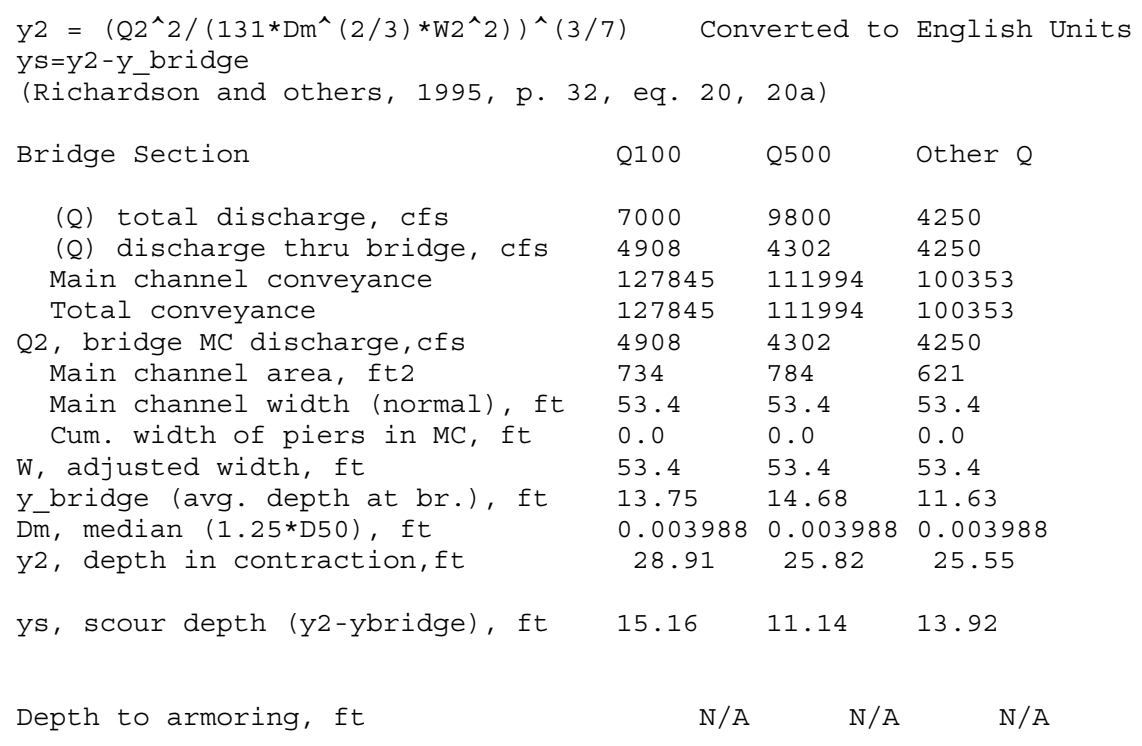


Abutment Scour

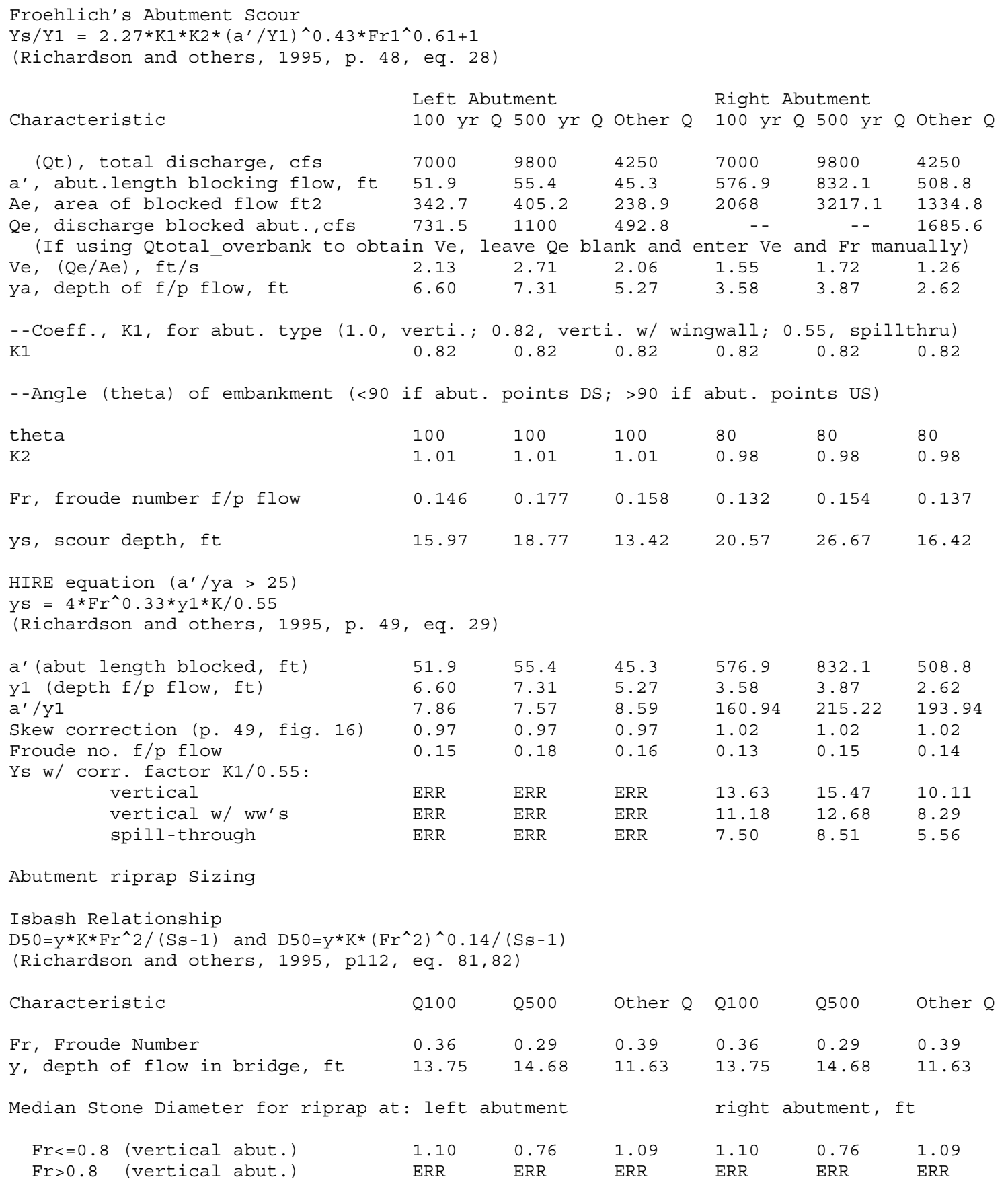

